UC-70

Issued: August 1882

LA--9427-Vol. I

DE83 008739

\title{
The Los Alamos Controlled Air Incinerator for Radioactive Waste. Volume I. Rationale, Process, Equipment, Performance, and Recommendations
}

\author{
A. S. Neuls \\ W. E. Draper \\ R. A. Koenig \\ J. M. Newmyer \\ C. L. Warner
}

\section{DISCLAIMER}

This report was prepared as an account of work sponsored by an agency of the Uaited States Government. Neither the United States Government nor any agency thereof, nor any of their employees, makes any warranty, express or implied, or assumes any legal liability or reaponibility for the accuracy, completeness, or usefulness of any information, apparatus, product, or process disclosed, or represents that its use would not infringe privately owned rigitus Reference herein to any specilic commercial product, process, or service by trade mame, trademart, manufacturer, or otherwive does not necessarily constitute or imply its eadorseneath recommendation, or favoring by the United States Government or any aseacy thereof. The views and opinions of authors expressed herein do not necessarily state or reflect thowe of the United States Government or any agency thereof.

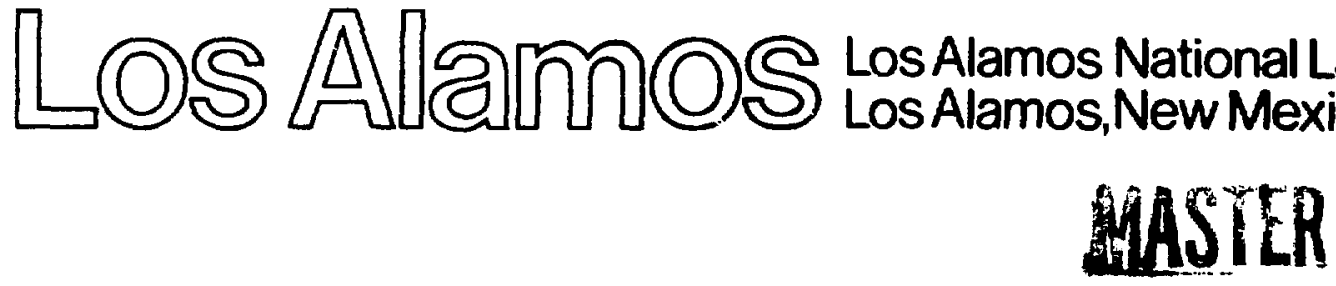




\section{CONTENTS}

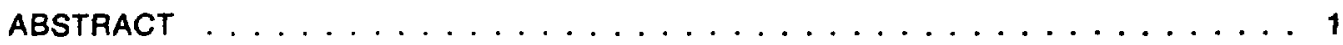

1.0 Summary .............................. 1

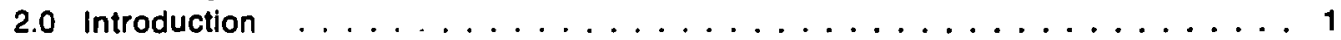

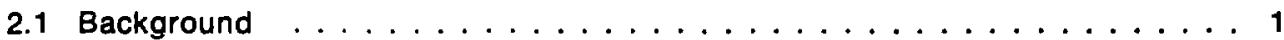

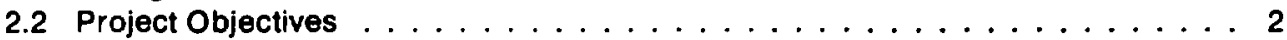

2.3 Process Objectives ....................... 2

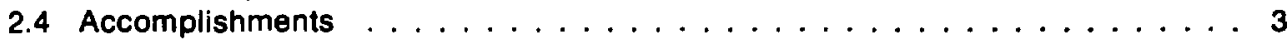

2.5 Future Plans . . . . . . . . . . . . . . . . . . 4

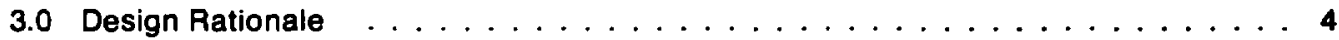

3.1 Design Basis . . . . . . . . . . . . . . . . . . . . 4

3.2 Process and Component Selection Criteria $\ldots \ldots \ldots \ldots \ldots$

3.3 Design Goals . . . . . . . . . . . . . . . . . . . . 5

3.4 Design and Pertormance Review ................. 7

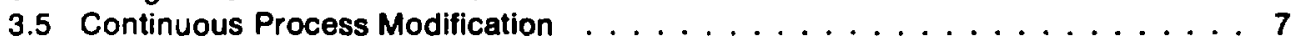

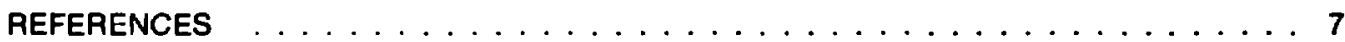

4.0 Process Description $\ldots \ldots \ldots \ldots \ldots \ldots \ldots \ldots$

4.1 Introduction $\ldots \ldots \ldots \ldots \ldots \ldots \ldots \ldots \ldots$

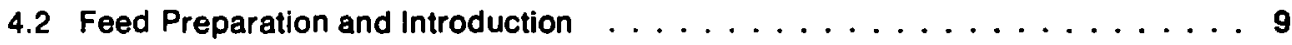

4.3 Incineration $\ldots \ldots \ldots \ldots \ldots \ldots \ldots \ldots \ldots \ldots$

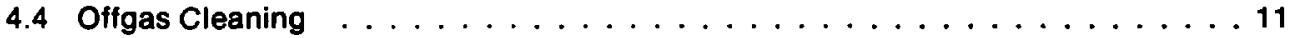

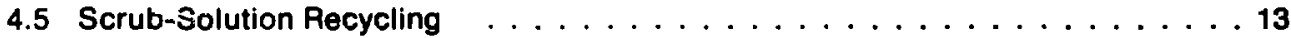

4.6 Ash Removal . . . . . . . . . . . . . . . . . . . . . 14

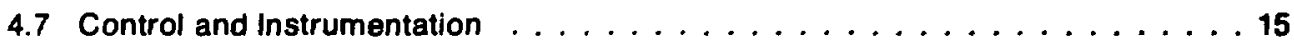

4.8 Process Utilities . . . . . . . . . . . . . . . . . 15

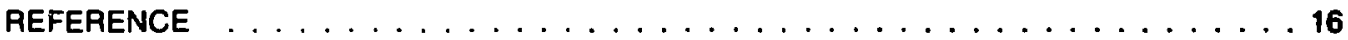

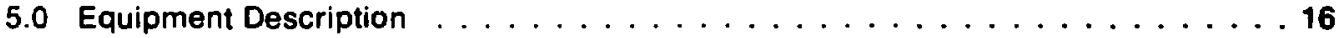

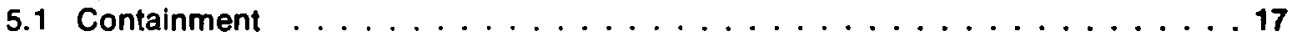

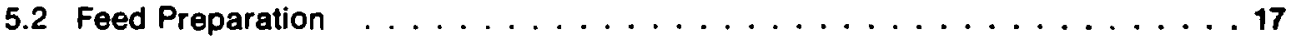

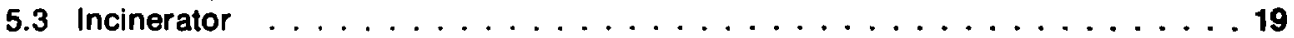

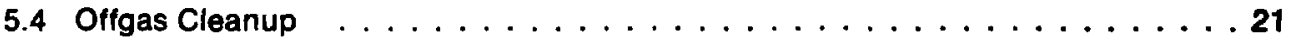

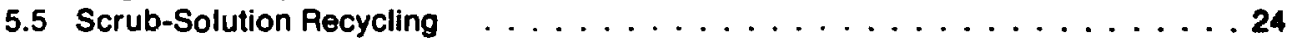

5.6 Ash Rernoval and Packaging ...................... 24

5.7 Process Utilities . . . . . . . . . . . . . . . . 26

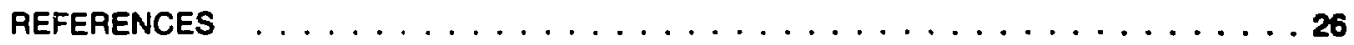

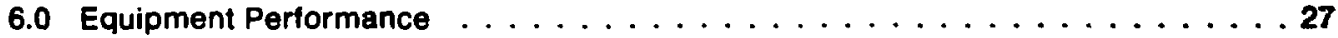

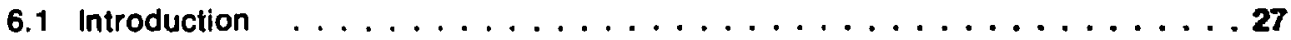

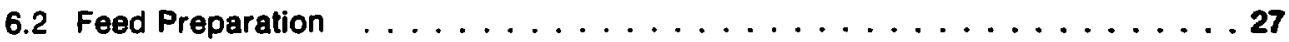

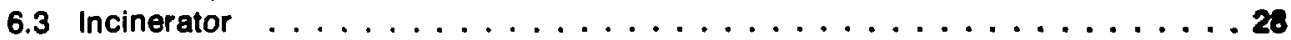

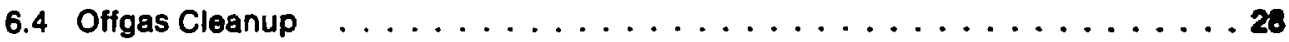

6.5 Scrub-Solution Recycling $\ldots \ldots \ldots \ldots \ldots \ldots$

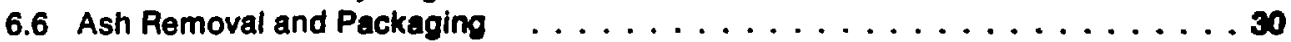

6.7 Process Utilities . . . . . . . . . . . . . . . . . 32 


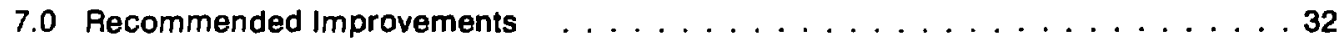

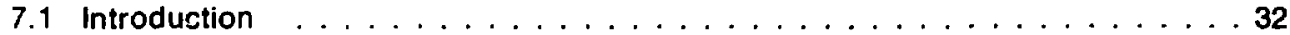

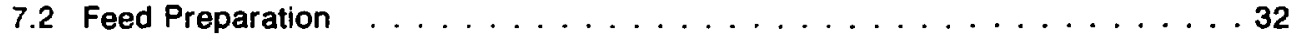

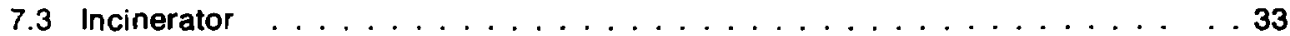

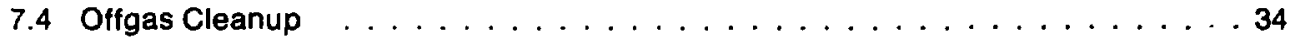

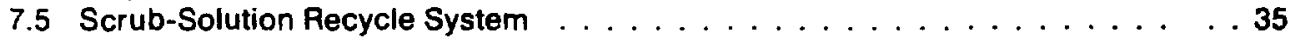

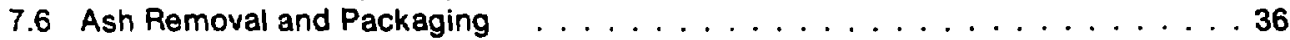

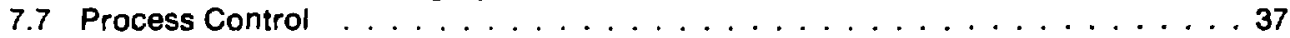

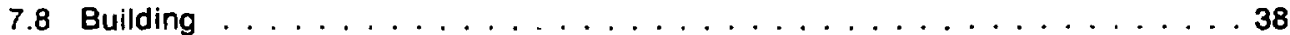

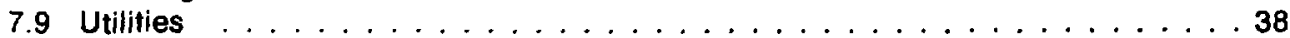

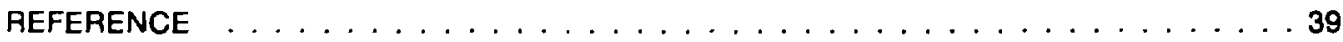

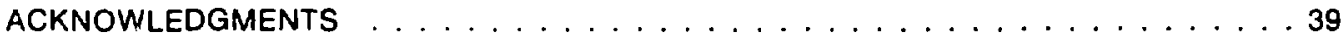




\title{
THE LOS ALAMOS \\ CONTROLLED AIR INCINERATOR \\ FOR RADIOACTIVE WASTE
}

Volume I: Rationale, Process, Equipment, Performance, and Pecommendations

by

A. S. Neuls, W. E. Draper, R. A. Koenig, J. M. Newmyer, and C. L. Warner

\begin{abstract}
This two-volume report is a detailed deaign and operating documentation of the Los Alamos National Laboratory Controlled Air Incinerator (CAI) and is an aid to technology tranafer to other Department of Energy contracter sties and the commercial sector. Volum I deseribes the CAI process, cquipment, and performance, and it recommends modifiestions based on Los Alames experience. It provides the necsasary information for concephusl deairn and feasibility studies. Volume II provides deseriptive engineering information such as drawings, specifications, calculations, and costs. It sids duplication of the process at other fasilities.
\end{abstract}

\subsection{SUMMARY}

In 1973, Los Alamos National Laboratory began a study of production-scale [50-100 $\mathrm{kg}(110-220$ (b) $/ \mathrm{h}$ ] transur\&inic (TRU) waste treatment processes. A controlled air incinerator (CAl) of 45kg (100-lb)/h capacity was selected for development and engineering demonstration. Nonradioactive (cold) testing of the CAl began in 1978, radioective (hot) testing in 1979. The CAI has been teeted with TRU and low-level waste* since 1980. Dotalled documentation of design considerations, process, equipment, performance, and recommendations for improvement follows. Section 2 is an overview of the history, objectives, eccompliahments, and future plans for the Los Alamos CAl project. Section 3 details health and safoty, function, and technical concerns reflected in the CAI design rationale

-TRU wastes, delined as >10 nCi/g (370 Bq/g) above uranium, are stored; low-level wastes (LLW), defined as $<10 \mathrm{nCi}(370 \mathrm{~Bq}) / \mathrm{g}$ above uranium, are burled. and discusses design criteria. Section 4 deacribes the incineration process from feed preparation through burning, offoas cleaning, scrub-solution recycling, ash removal and packaging, control and instrumentation, and auxiliary equipment. In Sec. 5 , all equipment used in the CAl is described. Equipment performance is the subject of Sec. 6. Fecommended improvements based on obeervation of the Los Alamos operation are discuseed in Sec. 7.

\subsection{INTRODUCTION}

\subsection{Deckround}

In 1973, the Waste Menegement Division of the Atomic Energy Commiselon (AEC), now under the ausplese of the US Depertment of Enery (DOE), funded Los Alamos Nationd Labortiony to oveluan alternative production-ecale treatment procesase 
for TRU solid wastes. Los Alamos responded with the Treatment Development Facility (TDF, Fig. 2-1) to house development and demonstration of experimental volume reduction processes. Incineration was chosen as the first process to be evaluated because (1) it is a time-honored method of reducing waste volumes, (2) it is well established in nonnuclear industrial applications, and (3) it seemed the most attractive of the volume reduction technologies available in 1973. The CAl system (Fig. 2-2) was selected because the immediate need to solve the TRU waste volume problem dictated the use of off-the-shelf components wherever possible. Of the available commercial incineration systems, the CAl has the right blend of flexibility in handling various waste types, ease of combustion rate control, low particulate emissions, and completeness of combustion. Offgas cleanup component selection of a high-energy aqueous scrubber with a variable orifice venturi and packedcolumn aosorber was based on the need for rapid adjustment to widely varying incinerator waste feeds and high-efficiency removal of particulates and inorganic acids, (primarily $\mathrm{HCl}$ ). The design phase began in 1974, and construction of the TDF began in 1976. Nonradioactive testing began in 1978 , the first radioactive test was completed in December 1979, and the demonstration run was made in April 1980. Emphasis since then has been on documentation.

\subsection{Project Objective:}

Objectives in the CAl development project were

(i) assembling and operating a state-of-the-art production incinerator system using commercially available incineration and pollution-control components;

(2) meeting radiosctive health and safety standards; and

(3) defining the advanteges and limitations of conventional technology.

\subsection{Process Objectives}

The primary CAl process objective is to reduce by incineration the volume of DOE-contractor TRU wastes. Meeting this goal has wide economic ramifications because combustibles account for a significant portion of waste volume.

Another major objective is chemical stabilization-the elimination of combustibles and the oxidation of contained radionuclides. Effective incineration destroys many toxic chemicals and produces an inert waste form compatible with recovery, immobilization, and disposal. Processing waste by incineration also decreases the possibility of gas generation caused by decay of organic materials. Alpha attack on cellulosic structure, or radiolytic degradation, is the most common gasproducing mechanism associated with TRU waste

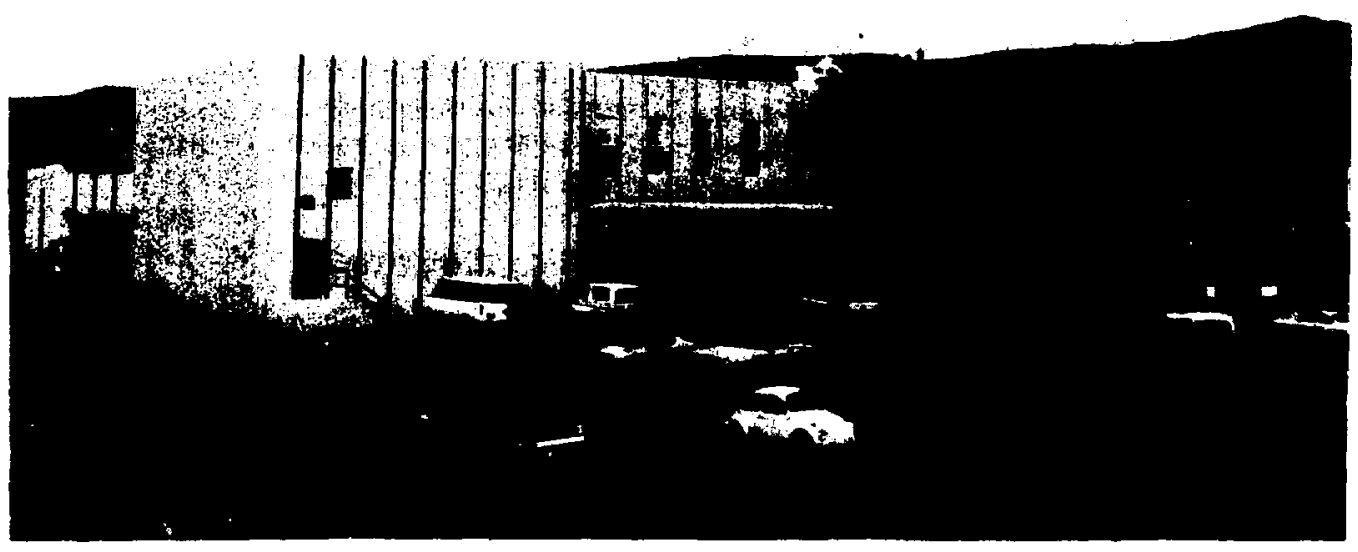

Fig. 2-1. Treatment Development Fecillty (TDF). 


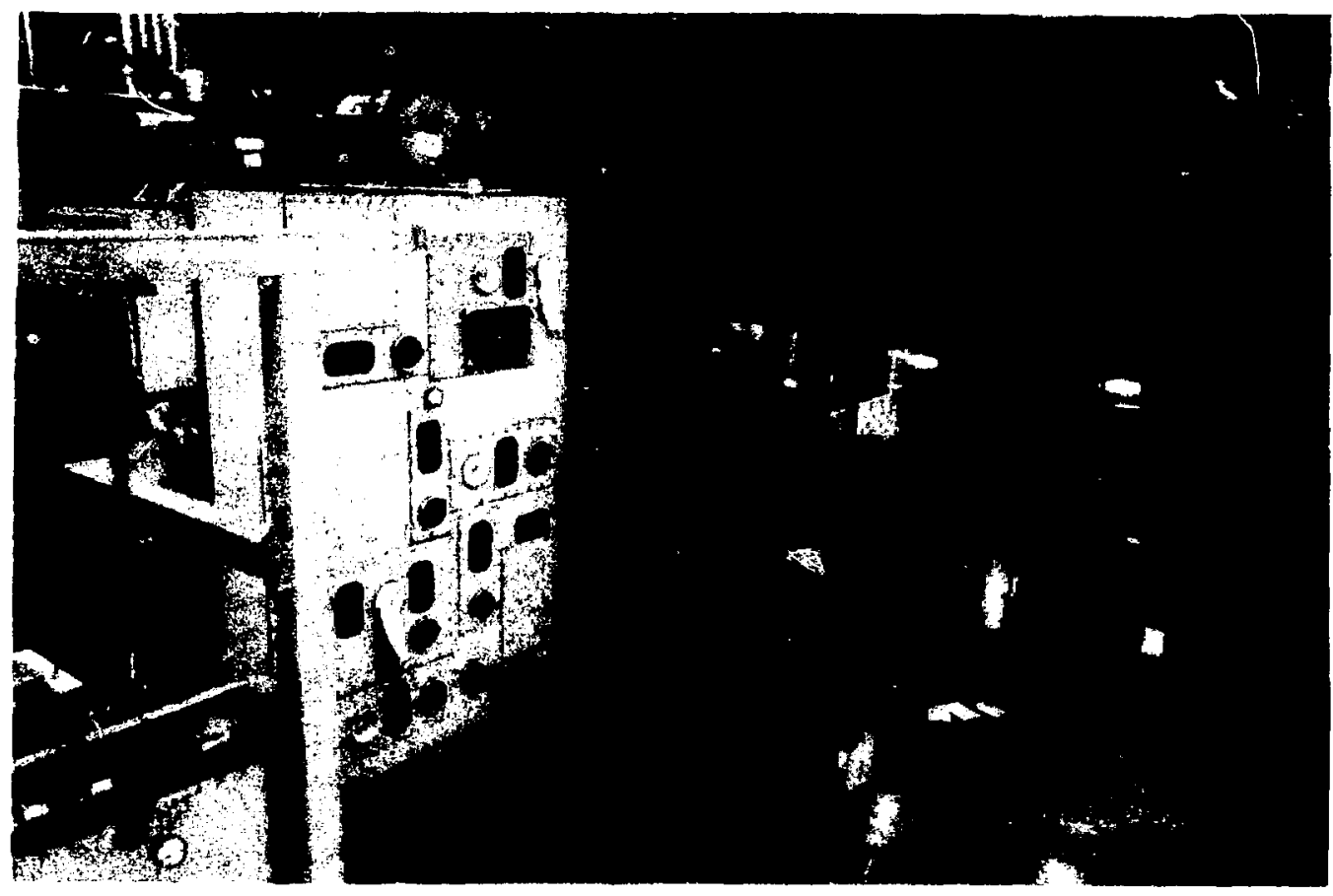

Fig. 2-2. Controlled Air Incinerator (CAl).

storage. This mechanism produces hydrogen, methane, and carbon monoxide, among other products. Incineration eliminates radiolytic gas generation, as well as composting and associated pyrolysis, completely.

\subsection{Accomplichments}

After initial component checkout, six test runs were made with uncontaminated waste. These tests established operating parameters, identified modification needs, and allowed tuning of control loops and evaluation of safety and containment. This sievelopment phase yielded a process with e:ihanced operability, improved safety, and greater effectiveness. Specific accomplishments included (1) attainment of desired design throughput, (2) successful operation of all subsystems, (3) highly effective offgas cleanup resulting in chloride concentrations of $<8 \mathrm{ppm}$ and sulfate concentrations of $<10 \mathrm{ppm}$ in the condensate, and (4) long HighEfficiency Particulate Air (HEPA) filter life, with one set of filters in use for more than $230 \mathrm{~h}$. Data and experience gained during nonradioactive testing were applied in designing process modifications necessary for radioactive service.

Two test runs then verified the integrity and performance of the complete CAl system with actual radioactive waste as the feed. The first test with radioactive materials used suepect TRU waste coinsisting of room trash from the Laboratory Plutonium Processing Facility. A total of $3.68 \mathrm{~m}^{3}$ (130 $\left.\mathrm{ft}^{3}\right)$ of waste weighing about $213 \mathrm{~kg}(470 \mathrm{lb})$ was incinerated to produce $0.03 \mathrm{~m}^{3}\left(1 \mathrm{ft}^{3}\right)$ of ash wolghing $7.26 \mathrm{~kg}(16 \mathrm{lb})$, resulting in woight and voumo reductions of 29:1 and 130:1, respectively. These reduction factors were somewhat higher than expected because of the low density and high plastic content of the waste material.

The next run was a TRU-waste demonstration in which $3.44 \mathrm{~m}^{3}$ (121.5 $\mathrm{ft}^{3}$ ) of feed wolghing $272 \mathrm{~kg}$ (598 lb) and containing an average of $20 \mathrm{nCl} / \mathrm{g}(740$ $\mathrm{Bq} / \mathrm{g})^{230} \mathrm{Pu}$ plus ${ }^{24} \mathrm{Am}$ wes burned. The incinerator was operated at feed rates of $24.5 \mathrm{~kg}(54 \mathrm{~kb}) / \mathrm{h}$ and $45 \mathrm{~kg}(100 \mathrm{lb}) / \mathrm{h}$ during the run. About $6.8 \mathrm{~kg}(15 \mathrm{lb})$ of ash with a volume of lose than $0.03 \mathrm{~m}^{3}(1 \mathrm{ft}) \mathrm{mas}$ removed, resulting in woight and volume reductions of 40:1 and 120:1, respectiveby. 
During these runs, the system performed well with no contamination problems observed. These tests proved the integrity of all subsystems and specific historical trouble spots such as the offgas system, the HEPA filter system, and the ash-removal and packaging system.

\subsection{Future Plans}

In the future, equipment and operation procedures will be developed and tested to expand CAl process applications to incinerating ion exchange resirs (beaded and powdered), a wide range of organic liquids, and nuclear utility LLW. Resin combustion studies will be completed near the end of 1982; liquid studies will start in 1982.

A commercialization program to bring the level of design, development, and documentation to the point where a nuclear utility could obtain a Nuclear Regulatory Commission license for installing and using the LLW treatment process at a selected site will be completed by Los Alamos and DOE in 1983. This program includes tracer-level tests to determine ruthenium, cesium, iodine, iron, and cobalt distribution. These tests began in 1981 and are continuing in 1982.

\subsection{DESIGN RATIONALE}

The rationale underlying the CAl design (1) would ensure the safety of the operators, the public, and the environment, (2) would take into account past experience at Los Alamos and other facilities to capitalize on their successes and avoid their shortcomings, and (3) would be on the leading edge of developed technology where possible. The design basis, or starting point, was the volume reduction of radioactive waste by an efficient method that could be put ints service as soon as possible. Once the method--incineration-was settled on, specific processes and components had to be selected according to some systematic plan. These selection criteria had to satisfy the design goals of safety and function. After the system was designed and built, its performance needed to be evaluated. Finally, if performance evaluation revealed a need for modification, potential for positive change had to be a part of the design rationale from the very beginning.

\subsection{Design Basis}

The Los Alamos process is designed to handle wastes resulting from transuranic operations. Los Alamos decided to explore incineration as a TRU waste disposal method because incineration technology was well developed. Therefore, most of the design effort could be directed to modifications for radioactive service. Another advantage of incineration is that it is highly efficient.

Early in the Los Alamos CAl effort, a review of active and inactive incinerators for treatment of radioactive wastes was completed. The conclusions of this report ${ }^{3.1}$ detailed major problem areas and served as a guide against pitfalis. After this review, the controlled air process was selected as the most suitable for development.

The CAl system had to be designed to handle waste originating from laboratories, processes, and construction. Table 3-1 shows the range of waste compositions anticipated for these categories. based on an AEC industry-wide survey made by Los Alamos in $1973 .^{3-2}$

The design also had to encompass a way of dealing with typical design feed. Process design feed includes any materials treatable by incineration. Materials ineffectively reduced by or incompatible with the process needed to be sorted for disposal by other means. The design basis feed for conventional incineration is given in Table 3-2. Heat

\begin{tabular}{|c|c|c|c|}
\hline TABLE 3-1. & $\begin{array}{l}\text { Oefed DOE-C } \\
\text { Comporition }\end{array}$ & ontrector & ecility Typical \\
\hline Material & $\begin{array}{l}\text { Laboratory } \\
\text { (wts) }\end{array}$ & $\begin{array}{l}\text { Procees } \\
\text { (mits) }\end{array}$ & $\begin{array}{l}\text { Cenatruction } \\
\text { (wix) }\end{array}$ \\
\hline Paper and rage & $10-60$ & $10-40$ & $5-20$ \\
\hline Plastics & $5-\infty 0$ & $20-40$ & $5-30$ \\
\hline Rubber & $5-30$ & $10-45$ & $5-20$ \\
\hline Lumber & -.+ & $\cdots$ & $5-30$ \\
\hline Dirt and concrete & $-\infty$ & $\cdots$ & $5-60$ \\
\hline Metallics and glase & $5-50$ & $30-40$ & $10-50$ \\
\hline
\end{tabular}

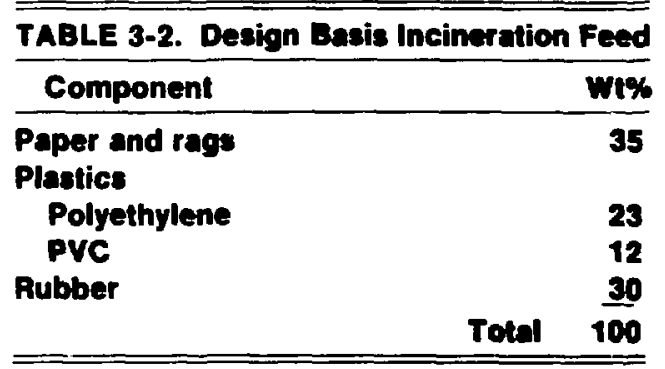


and material balances required for equipment sizing were based on this composition. The Los Alamos CAl process can handle $100 \%$ of any of these waste components at a $10-\mathrm{kg}(20-\mathrm{lb}) / \mathrm{h}$ feed rate, and the offgas cleaning system can scrub up to $100 \%$ of the mineral acids and particulates generated for any component, including PVC.

\subsection{Process and Component Selection Criteria}

The CAl process functions through a chain of individual equipment units. Almost without exception, each unit's operation could be effected with more than one type of equipment. For example, a list of devices to remove air-stream particulates could include both venturi scrubbers and cyclone separators. Therefore, a systematic, rational method for selecting components had to be devised to achieve the best possibie process.

Counteracting a tendency to make subjective choices was one important goal of this part of the design rationale. Because most people responsible for selecting process equipment for a specific application have considerable experience in that field, many have a feeling for what they consider to be the best equipment to perform a required function. These judgments, developed from reading, word of mouth, and past experiences, can be very subjective. The lack of objectivity often leads to disagreements about equipment recommendations and can result in acquiring equipment with service applications that are too limited. To countersct this tendency, the Los Alamos Waste Management Group developed a procedure to assist objective selection of the best equipment to perform specific functions. ${ }^{3-3}$

Reference 3-3 addresses the use of the evaluation procedure in comparing whole processes. Generally, evaluation criteria and methods remain the same when evaluating components.

Briefly, the procedure involves six steps:

(1) Definition of unit boundaries;

(2) Definition of overall function or objective of unit;

(3) Identilication of evaluation criteria; (Each criterion is quantified by performance measures expressed a!j numbers called levels of performance.)

(4) Development of value functions, which determine worth as a function of each level of performance;

(5) Weighing of evaluation criteria relative to one another; and
(6) Combination of worth/weight for each criterion to produce a single scalar of overall process/component worth.

Examples of evaluation criteria and definitions are

(1) Effectiveness-the unit's ability to achieve its design function. The performance measure for effectiveness can be defined as the ratio of actual performance to maximum theoretical performance.

(2) Flexibility-the unit's ability to accept and act on a range of input compositions and varying throughputs. The pertormance measure for flexibility can be defined as the effect on unit effectiveness when operating with varying degrees of input composition and throughput away from design input specifications.

(3) Availability - the ability of a unit to remain operational, including the unit's maintainability and reliability. The direct measure is the percentage of uptime.

(4) Operability-the level of operational complexity in terms of control and workers. The performance messure is the minimum number of parameters that must be controlled for the unit to operate and meet functional and health and safety requirements. Controlled ancillary or extra variables not necessary for unit operation are not included.

(5) Resource Use-intrinisic consumption of energy, scarce materials, water, and land. Performance measures for these subcriteria are categories of use-extensive, very high, high, moderate, low, very low, none. While operational costs are at least partially embodied in resource use, capital costs are not considered.

\subsection{Design Cosls}

Once the most appropriate processes and components were selected using the design criteria, they had to be adapted for TRU service. Modifications to incorporate safety features, modular construction, and extensive instrumentation were designed and implemented into the overall operation. Another important design goal was to keep the process and equipment as simple as posible.

3.3.1 Component and Proceses enisty. The total effort to ensure component and process satety has been extensive. As a minimum, cquipment must satisfy the requirements of the "Cenerel inciustry Safoty and Health Regulations, Part 1910," with 
amendments as issued by the Occupational Safety and Health Administration..$^{3-4}$ in addition, equipment with intrinsic safety concerns, such as highspeed rotating parts or high-temperature surfaces, was downgraded during the selection process or given special attention when selected. Interlocks, lockouts, guards, position indicators, actuation signals, heat shields, splash shields, splash curtain, auxiliary bypasses, and auxiliary manual operators have been engineered into the design to enhance safety. Combustion safeguards were upgraded to meet the most stringent identifiable standards.

3.3.1.1 Double-failure Concept. An area closely related to health and safety is the modification of certain critical components to require at least two equipment or supply failures before component function is impaired. Examples are

- double seals at critical flanges,

- independent auxiliary supplies for utilities except fuel gas and steam,

- use of double-check valves,

- auxiliary routing of liquid lines so that one pump is backed by another, or so that substitute liquid can be used, and

- use of corrosion resistant materials to back up the $\mathrm{pH}$ control system.

\subsubsection{Containment. Airborne dispersion of} alpha-:adiation and subsequent inhalation of particulates is one of the hazards associated with handling TRU contaminated materials. The incinerator and the facility supporting it must contain any airborne contamination to prevent release to the atmosphere and to keep dose levels to operating personnel as low as is reasonably achievable.

Building ventilation is zoned such that air moves from areas of low potential for contaminatior to areas of higher potential for contamination ien through double HEPA filters before release the atmosphere. In this way, dispersion of aii w rne contamination is prevented. Other features to ensure containment, such as double seals at hightemperature flanges, were routinely incorporated into process design.

All routine work with TRU materials is done in gloveboxes which are completely sealed and leak tested before use. All points on the incinerator where access is required are fitted with gloveboxes to contain airborne contamination within the process.

3.3.1.3 Contact Maintenance. Extensive modification has moved components that are difficult to maintain or that require routine servicing into areas not expected to be contaminated. Therefore, items such as chain drives, hydraulic pump stations, and controls can be serviced with substantially reduced risk of worker exposure to contamination. This effort has completely eliminated the need for airsuits during maintenance.

3.3.2 Modular Construction. Modular construction allowed rapid modification or substitution of components during the development phase. In TRU service, maintenance and decontamination costs can be substantial, in many cases exceeding the replacement cost of the equipment used. Therefore, system design should be modular to allow access for replacement of failed components.

3.3.2.1 Off-the-Sheff Components. The use of off-the-shelf components in the CAl process reduces manpower requirements for design and development. Fabrication efforts are limited to modification for radioactive waste service. Another benefit of using off-the-shelf components is that they are readily available if replacements are needed.

3.3.2.2 Capital and Oporational Costs. Because of the extreme difficulty and high expense of servicing contaminated equipment, high capital and/or operational costs are justified if significant increases in operability and/or availability (maintainability, reliability) are realized.

Embodied in this rationale are

- justified use of expensive materials and

- component replacement in which the process units are assembled to permit removal and replacement of any damaged and contaminated equipment, the cost of which has been judged lower tran the cost of repairing or refurbishing these components.

3.3.3 instrumentation. A development project needs to hold constant as many process variables as possible while the effect of a selected variable is studied and documented. Hence, the CAl process instrumeritation was designed for flexibility that resulted in more components than those required of a production unit. Also, critical or important control variables or schemes were not evident before substantial operating experience with the process had been accrued. 
3.3.4 Simplicity. The whole CAl process reflects a design rationale that prefers simple devices, sometimes at the expense of efficiency, to facilitate operation, maintenance, and transfer of the design process to other facilities. For example, Los Alamos decided to sacrifice heat recuperation by direct contact with flue gas because its benefits are offset by maintenance requirements in a radioactive environment and difficulties attendant with most high-temperature heat-transier devices. Also, heat recuperation would have macie the design more complex than the design rationele called for.

\subsection{Design and Performance Review}

A safety review conducted immediately after process construction was complete resulted in numerous system changes to upgrade safety to the level described in the Final Safety Analysis Report (FSAR). ${ }^{3.5}$

Throughout the testing program, design flaws have been identified. A systematic checkout of the process and of safety components was carried out during the nonradioactive testing phase.

3.4.1 FSAR. Before inauguration of the CAI for TRU waste incineration, a comprehensive safety analysis of the system was completed and published. The FSAR addresses all aspects of system operation as they relate to the health and safety of operating personnel and the general population. It also details engineered safeguards-component and process safety, double-failure concept, ease of maintenance, and containment-through which health and safety concerns are satistied.

The "Controlled Air Incinerator Process Operating Manual" also details safety precautions and operating procedures for each subsection.

3.4.2 Performance Evaluation. The performance of the CAl has been monitored and evaluated continuously. Observations on the performance of each subsystem are detailed in Sec. 6.

*Available from Los Alamos Waste Management Group H-7, MS E517, Los Alamos National Laboratory, Los Alamos, N.M. 87545, 505-667-7391, on request.

\subsection{Continuous Process Modification}

Process faults of various magnitudes were detected as the project progressed. Where practical, these faults were anialyzed and corrected. Los Alamos chose this approach to enable the process to advance to a higher and more proven state of design rather than simply noting faults and then making recommendations for fault correction to possible users. All process and safety concerns were addressed before tests with radioactive materials began.

\section{REFERENCES}

3-1. Betty L. Perkins, "Incinerator Facilities for Treatment of Radioactive Wastes: A Review," Los Alamos Scientific Laboratory report LA-6252 (July 1976).

3-2. D. E. McCurdy, R. Mulkin, C. J. Umbarger, $M$. Wheeler, and A. Zerwekh, "Studies of Sorting and Characterization of Plutonium Process and Room Generated Waste," Proc. of Second AEC Environmental Protection Conference (Washington DC, 1974), Vol. II, 1332, p. 985.

3.3. W. J. Whitty, "An Evaluation Procedure for Radioactive Waste Treatment Processes," Los Alamos Scien ific Laboratory report LA-8052MS (November 1979).

3-4. Occupational Safety and Health Administration, "General Industry Safety and Health Regulations, Part 1910," Federal Register 39 (June 27, 1974).

3-5. C. L. Warner, Ed., "Final Safety Analysis Report for the Transuranic Contaminated Solid Waste Treatment Development Facility," Los Alamos Scientific Laboratory report LA-7971MS (July 1979). 


\subsection{PROCESS DESCRIPTION}

\subsection{Introduction}

The center of the CAl process is a dual-chamber, commercially avallable unit modified for TRU service. The Los Alamos modified design accepts a low-density, combustible TRU waste and reduces it by a factor of up to $40: 1$ by weight and up to $120: 1$ by volume (Hef. 4-1) to produce a chemically stable dry product (Fig. 4-1). CAl components-a feed preparation and introduction train, an offgas cleanup system, a scrub-solution recycle system, and an ash-removal and packaging station-function as follows.

The feed preparation train

- assays feed material and

- removes any materials not suitable for combustion.

The offgas cleanup system

- removes particulates and acid gases from the effluent and

- conditions the gas stream for passage through HEPA filters before discharge.

The scrub-solution recycle system

- supplies liquids at required pressures to the offgas system and

- treats these liquids for recycle and discharge.
The ash-removal and packaging station

- transports residue from the incinerator to a hopper and

- places it in containers for disposal.

A more detailed representation of the process without the feed preparation and introduction train is presented in Fig. 4-2.

The waste stream accepted by the CAl contains low concentrations of TRU nuclides in a low-density matrix. The combustible waste composition shown in Table 3-2 was derived from Atomic Energy Commission (AEC) surveys (sse Ref. 3-4) and is the basis for incinerator desig:ı. In actual operation, feed composition can vary so much that at times only one component constitutes the entire feed stream. Los Alamos incinerator design allows for this and many o: her possibilities.

The AEC surtey determined that processing rates required at TRU generating sites nised to be in the $45-90 \mathrm{~kg}(100-200 \mathrm{lb}) / \mathrm{h}$ range based on $10-$ mionth, 5 day/wk, 24-h operation of a production incinerator to meet current waste generation rates. Anticipated future needs increase the t:pper limit to $230 \mathrm{~kg}(500 \mathrm{lb}) / \mathrm{h}$. For this experimental model, a nominal throughput rate of $45 \mathrm{~kg}(100 \mathrm{lb}) / \mathrm{h}$ was set following a review of scaleup factors, commercially available equipment sizes, and demonstration goals.

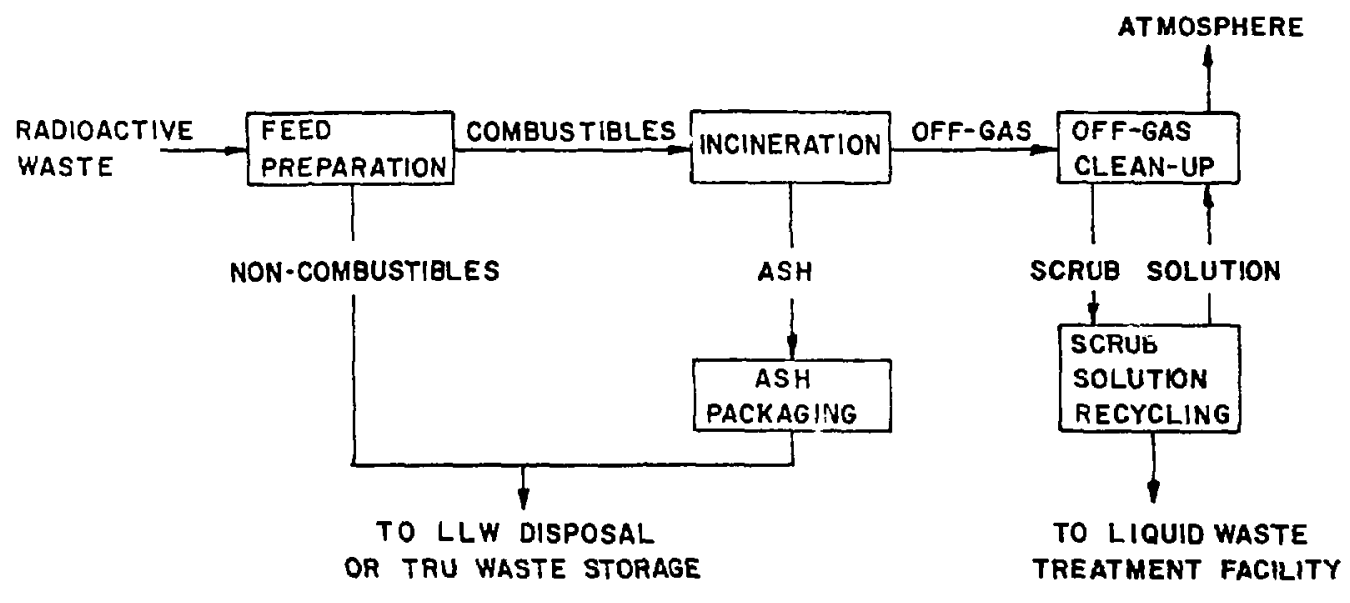

Fig. 4-1. CAl process llow diagram. 


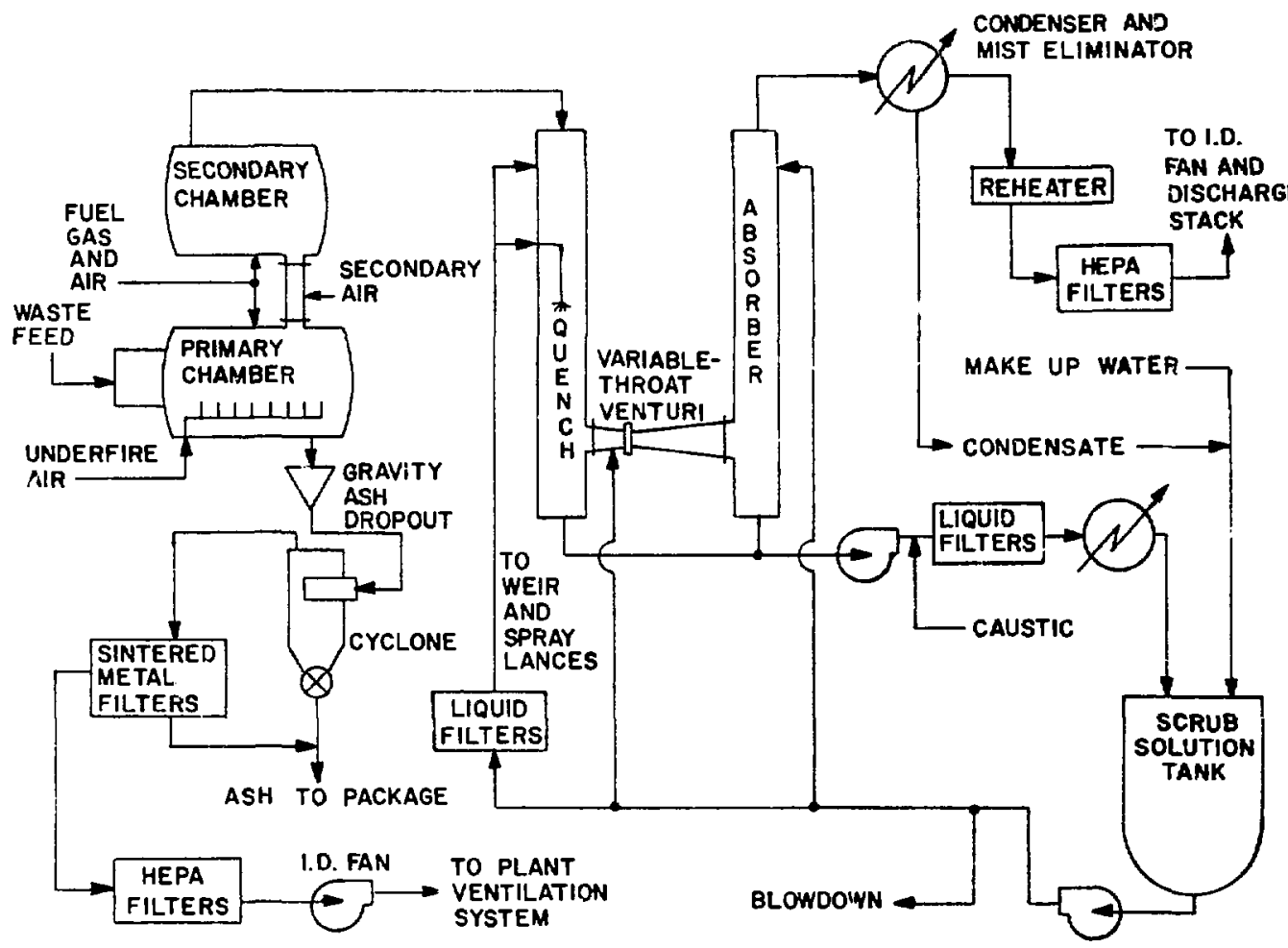

Fig. 4-2. CAl process schematic without feed preparation line.

\subsection{Feed Preparation and Introduction}

The feed preparation line assures a safe and convenient waste package for incineration while containing radionuclides anc minimizing waste handling, thereby reducing the potential for worker exposure. Component selection was dictated by both site-specific constraints and demonstration goals.

At Los Alamos, TRU wastes are sealed in plastic bags that are placed in $.3 \mathrm{~m} \times .3 \mathrm{~m} \times .6 \mathrm{~m}(1 \mathrm{ft} \times 1 \mathrm{ft}$ $\times 2 \mathrm{ft})$ cardboard boxes. Waste packages are first introduced into the receiving slotbox where their TRU content is assayed (Fig. 4-3). A Los Alamosdeveloped Multiple Energy Gamma Assay System (MEGAS), which is a nondestructive assay system, measures the TRU content near the $10 \mathrm{nCi} / \mathrm{g}$ ( 370 $\mathrm{Bq} / \mathrm{g}$ ) fiducial (see Fig. 5-1).

Next, the boxes pass through an $x$-ray assembly (see Sec. 5.2.4), similar to airport security equipment, which scans for materials incompatible with combustion such as large noncombustible items and bottles of liquid. If necessary, the packages are opened in the sorting glovebox, and these items are removed. After inspection and necessary sorting, waste packages are transported to the storage glovebox where enough waste is accumulated for about $5 \mathrm{~h}$ of incinerator operation. During incineration, waste packages are transferred manually from the storage box to the side-ram feeder and in turn are automatically loaded to the main feeder, which transports the boxes to the incinerator hearth.

\subsection{Incineration}

A CAl (Fig. 4-4) was selected mainly for mechanical simplicity and operability to minimize the high costs and risks associated with component fallure in processes involving both high temperatures and transuranic materials. Extensive fletd operation proved the reliability of CAl units when proceseing a variety of solid waste forms. Furthermore, the low turbulence in the primary combustion chamber and the resultant low carryover of particulates to subsequent offgas treatment made the controlled air concept most attractive. 


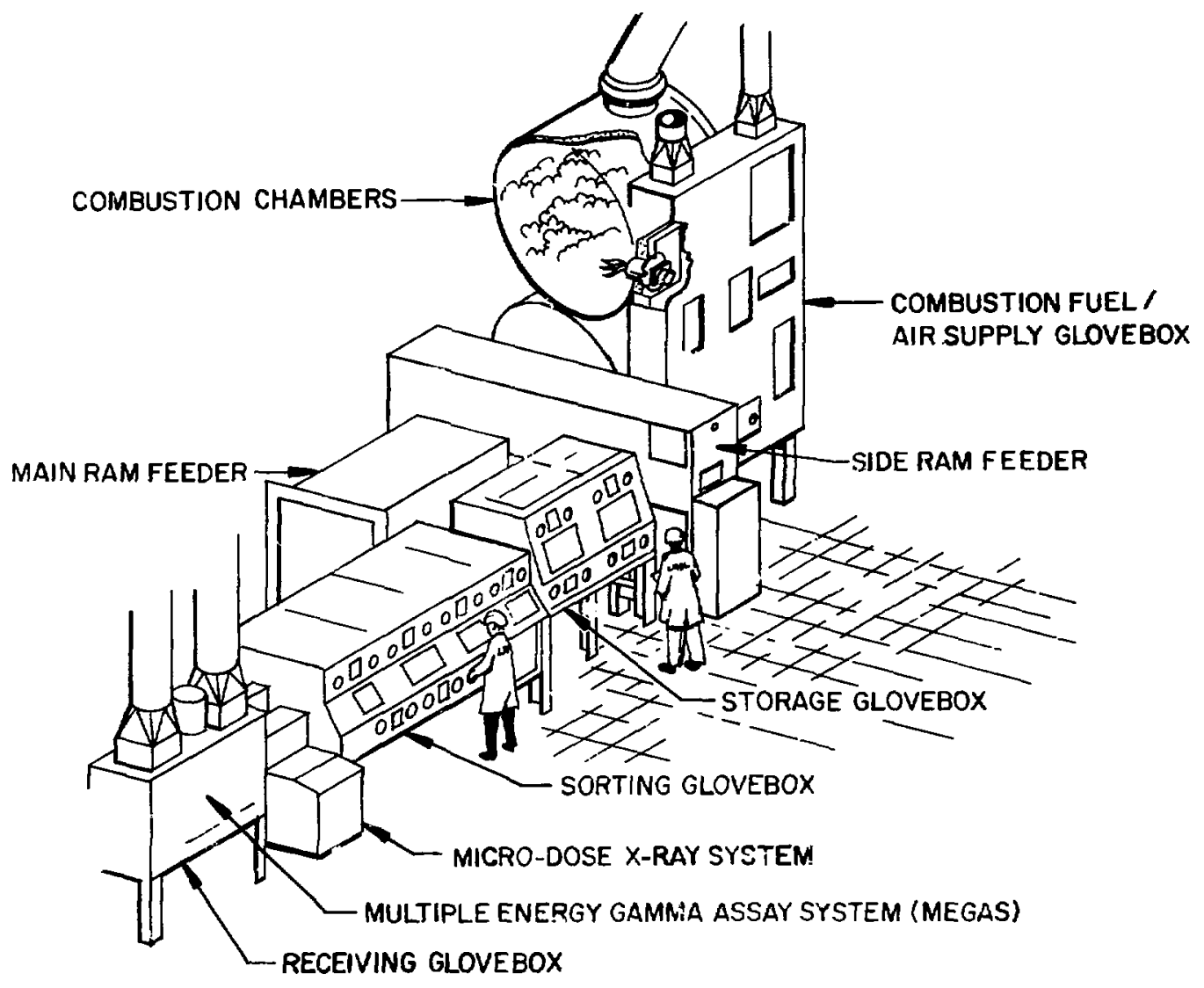

Fig. 4-3. Feed preparation line.

Though the Los Alamos incinerator was modified for $R$ \& D, similar unmodified models are frequently used for disposal of municipal, pathologicai, and industrial solid wastes. in all models, the dual chambers are refractory lined, and many models use naturai gas for waste ignition and supplemental heat. Wastes are charged batchwide by the main ram feeder io the lower, or primary, combustion chamber where underfire air supports combustion at near stoichiometric corditions (see Sec. 5.3.2). Unburned volatile compo,ients and entrained particles exit the lower chamber through an interconnecting duct where excess air is introduced to promote complete combustion while the upper, or seco rdary, combustion chamber provides needed residence time (see Sec.. 5.3.3). Normal operating temperatures are $870^{\circ} \mathrm{C}\left(1600^{\circ} \mathrm{F}\right)$ in the lower chamber and $1100^{\circ} \mathrm{C}\left(2000^{\circ} \mathrm{F}\right)$ in the upper chamber, with supplemental heat supplied to the upper chamber as needed. Air introduction rates and nominal chamber temperatures vary with waste combustion characteristics. The minimum calculated residence time in the upper chamber is $1.25 \mathrm{~s}$.

Because the incinerator is enclosed in a building with limited ventilation capacity, refractory/insulation for the incinerator was selected to produce a shell temperature of about $180^{\circ} \mathrm{C}$ $\left(350^{\circ} \mathrm{F}\right)$. To protect this relatively cool shell from strong acid attack when burning some types of rubber and plastic, the shell interior is coated with a diffusion barrier of a chlorinated-sulfonated elastomer commonly used in industry to coat acid stacks.

The incinerator burners were modified to increase combustion efficiency and chamber temperature conirol. The burners were also changed to a premix type to produce a highdensity flame. Fuel-gas combustion now occurs within or near the burner block and is less affected 


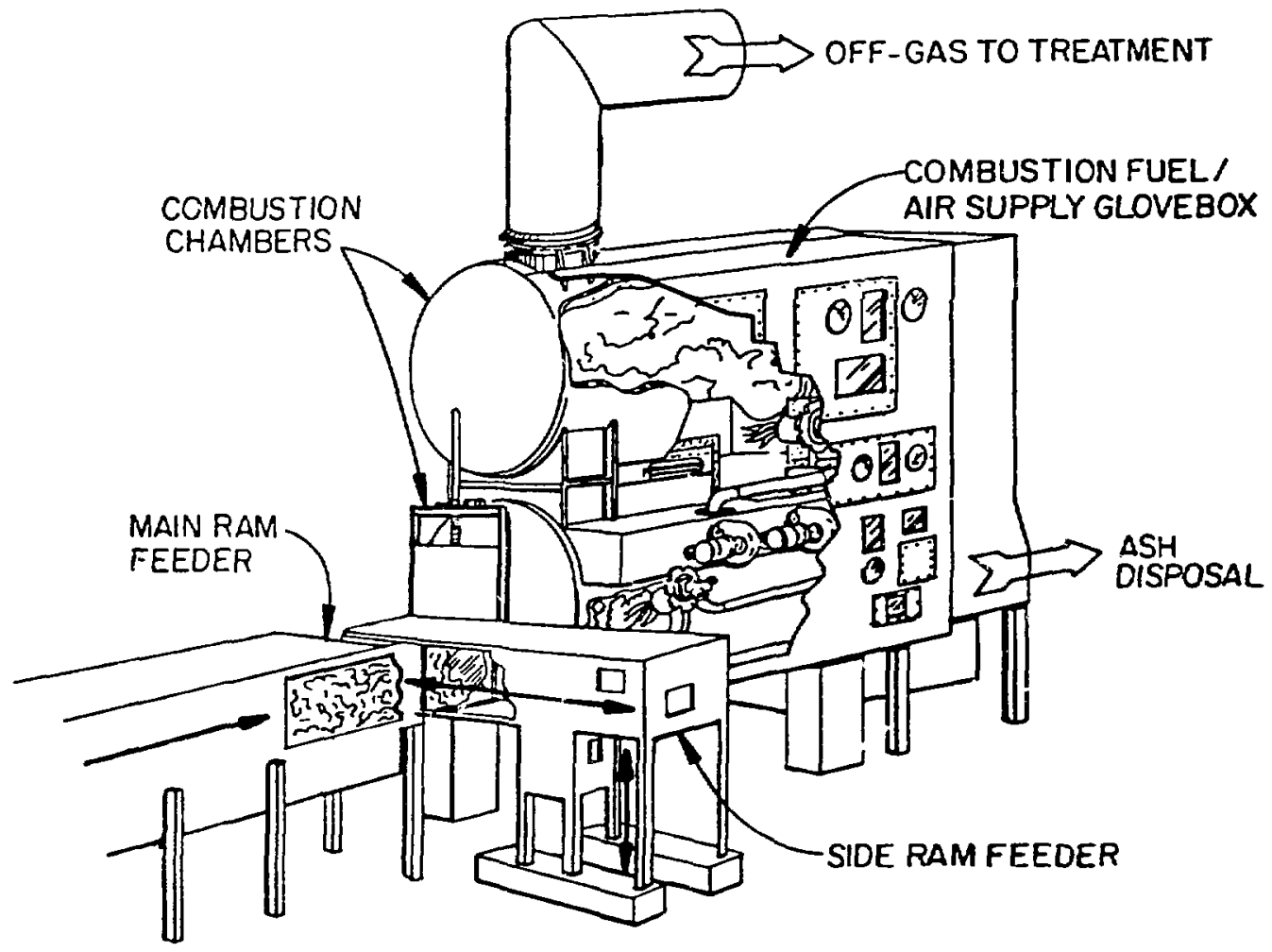

Fig. 4-4. Incinerator.

by the occasionaily oxygen-deficient chamber atmosphere. Burner controls were upgraded from an on/off mode to a modulating mode to permit closer control of chamber temperatures with changing incinerator heat loading. Combustion-air flow now varies in a direct ratio to fuel-gas flow, permitting greater dedication of underfire air as the oxidizing medium for burning waste material.

Steam injection was added to the lower chamber to promote specific combustion reactions. The resulting increased partial pressure of water in the combustion zone enhances both the water-gas shift reaction (accelerating the oxidation of carbon) as well as the conversion of free chlorine to a more easily removed chloride gas.

To further promote carbon burnout, the secondary air injection system was modified by the addition of a manifold with an increesed number of injection points to provide more intimate mixing of the excess air with products of partial combustion leaving the lower chamber. Oxygen control was improved $\mathrm{by}$ installing oxygen/combustibles analyzers at the exit of each chamber. These analyzers continuously monitor offgas from each chamber and control the level of excess air from each: the lower by adjustment of the underfire air flow and the upper by variation of the secondary air flow.

\subsection{Offgas Cleaning}

Component selection for the offgas cleaning train was also based mainly on function and operation. The system chosen has been extensively proven in the field by its application to a wide number of processes, including industrial incinerators that burn a range of hazardous materials.

Exhaust from the CAl upper combuation chamber can contain both particulates resulting from entrainment and generated minerel ecids, such as chlorides and sulfates. Theee chemical pollutants and potentially radioactive particles are removed by the offgas cleaning systom, which consists of a quench tower, a high-energy venturi 
scrubber, a packed-column absorber tower, a condensor, a mist eliminator, a reheater, a number of HEPA filters, and an induced-draft blower (Fig. 4-5).

In the quench tower, which is divided into an upper contacting section and a lower separating section, combustion gases are cooled from the incinerator exit temperature to approximately $70^{\circ} \mathrm{C}$ $\left(160^{\circ} \mathrm{F}\right)$ by evaporation of recycled scrub solution. Excess solution collects in the separator while the saturated-gas phase is routed to the inlet of the venturi scrubber.

The variable-throat venturi scrubber, between the quench tower and the absorber tower, removes up to $99 w t \%$ of particulates remaining in the offgas. The venturi assembly consists of converging and diverging cones with a clamp valve throat to allow adjustrient of the pressure drop. Venturi pressure drop is normall; controlled to $12.4 \mathrm{kPa}$ (50 in. W.G.). Scrub solution is injected through a nozzle upstream of the throat. Mineral acids are removed from the gas phase by counter-current contact with process condensate, recycled scrub solution, or fresh water in the packed-column absorber tower.

The condenser, mist eliminator, and reheater are included to condition the process exhaust gases before final HEPA filtration. The condenser lowers the offgas temperature, removing most of the water vapor from the scrubbed gas stream. The offgas is then reheated approximately $17^{\circ} \mathrm{C}\left(30^{\circ} \mathrm{F}\right)$ above the saturation temperature to avoid condensation and attendant plugging of the HEPA filters and corrosion of the plenum, exit ducting, and offgas blowers. The functional parts of each of these subsystem components are commercial equipment housed in enclosures specially designed to withstand the 27-kPa (110-in. W.G.) pressure differential betwean this process and ambient conditions.

HEPA filtration provides final particulate removal. The filter module contains two similar frames in series: the firs! a prefilter and two HEPA filters, the second without the prefilter. The filter housing is designed to withstand the 27-kPa (110in. W. G.) pressure differential capability of the process and is fitted with hatches to access the bagout doors and in-place filter testing ports.

Negative draft for the incinerator and offgas system is supplied by one of two induced-draft fans ducted in parallel. Each is capable of producing 57$\mathrm{kPa}\left(230\right.$-in. $\left.\mathrm{H}_{2} \mathrm{O}\right)$ static pressure absolute at $\mathbf{5 3 . 8}$ $\mathrm{m}^{3}\left(1900 \mathrm{ft}^{3}\right) / \mathrm{min}$ with a discharge pressure of 77 kPa $\left(310\right.$-in. $\left.\mathrm{H}_{2} \mathrm{O}\right)$ absolute [to accommodate the 2100-m (7,000-ft) elevation at Los Alamos]. The pressure differentid between the operating area

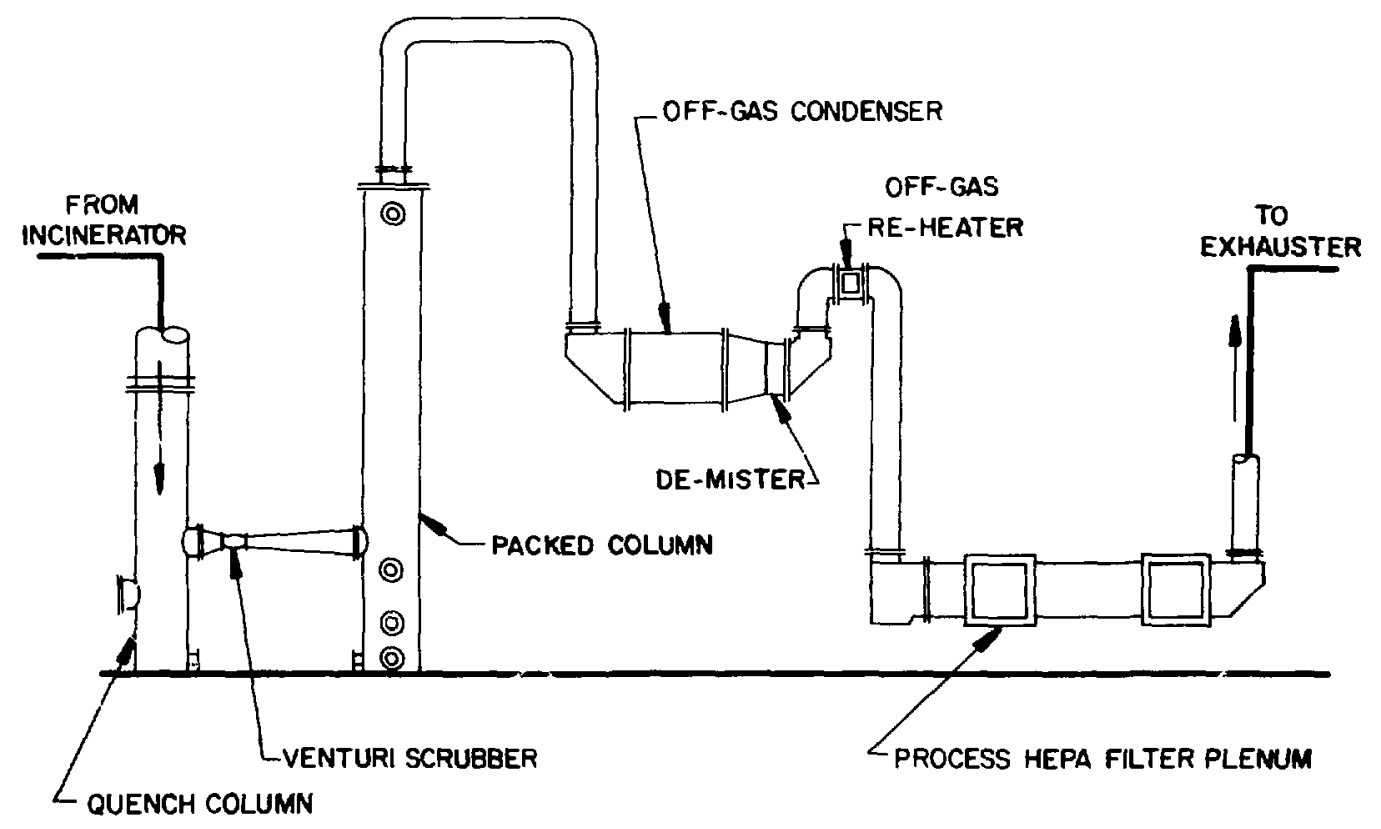

Fig. 4-5. Oligas cleaning system. 
and the incinerator interior is maintained by a pressure control loop which acts on flow-control valves at each induced-draft tan.

\subsection{Scrub-Solution Recycling}

Equipment selection for the scrub-solution recycling system considers the "double failure" concept (see Sec. 3.1.3) and proven technology. System design provides sufficient redundancy so that failure of any one component will not result in release of contaminants to the environment. Most of the equipment purchased has been proven by many years of operation in similar nonradioactive service.

This system uses a pH feedback arrarigement to control neutralization of the liquid effluent from the primary offgas scrubbing components. Effluent liquid is received from the offgas system, filtered, cooled, neutralized and recycled. Excess liquid is then removed from the system. The arrangement of this system is shown in Fig. 4-6.

Main components are the full-flow cartridge filters, the primary and secondary heat exchangers, the caustic injection system, the cooling water loops, the condensate collection system, and the process sump receiver tank.

Excess liquid drains from the bottom of the quench tower and combines with the venturi liquid and absorber tower effluent in the packed-column base. This solution is pumped through $100-\mu \mathrm{m} \mathrm{(4 \times}$ $10^{-3}$-in.) cartridge filters and a primary heat exchanger to the sump tank. Caustic solution at 20 $w t \%$ is added to the sump tank as needed. Liquid requirements for the quench tower, venturi scrubber, and the absorber tower are satisfied by recycled liquid pumped from the sump tank. Liquid supplied to the quench tower is refiltered by a 20um $\left(8 \times 10^{-4}\right.$-in.) cartridge filter to keep the small orifaced spray nozzles from plugging.

The primary heat exchanger cools recycling solution from $70^{\circ} \mathrm{C}\left(160^{\circ} \mathrm{F}\right)$ to $50^{\circ} \mathrm{C}\left(120^{\circ} \mathrm{F}\right)$. Cooling the process liquid increases the effectiveness of the quench tower and is believed to increase the performance of the venturi scrubber by permitting thermophoresis. The temperature of the quench liquid is controllec by varying the shell side flow of secondary cooling water in response to the process liquid outlet temperature. The process (tube) side

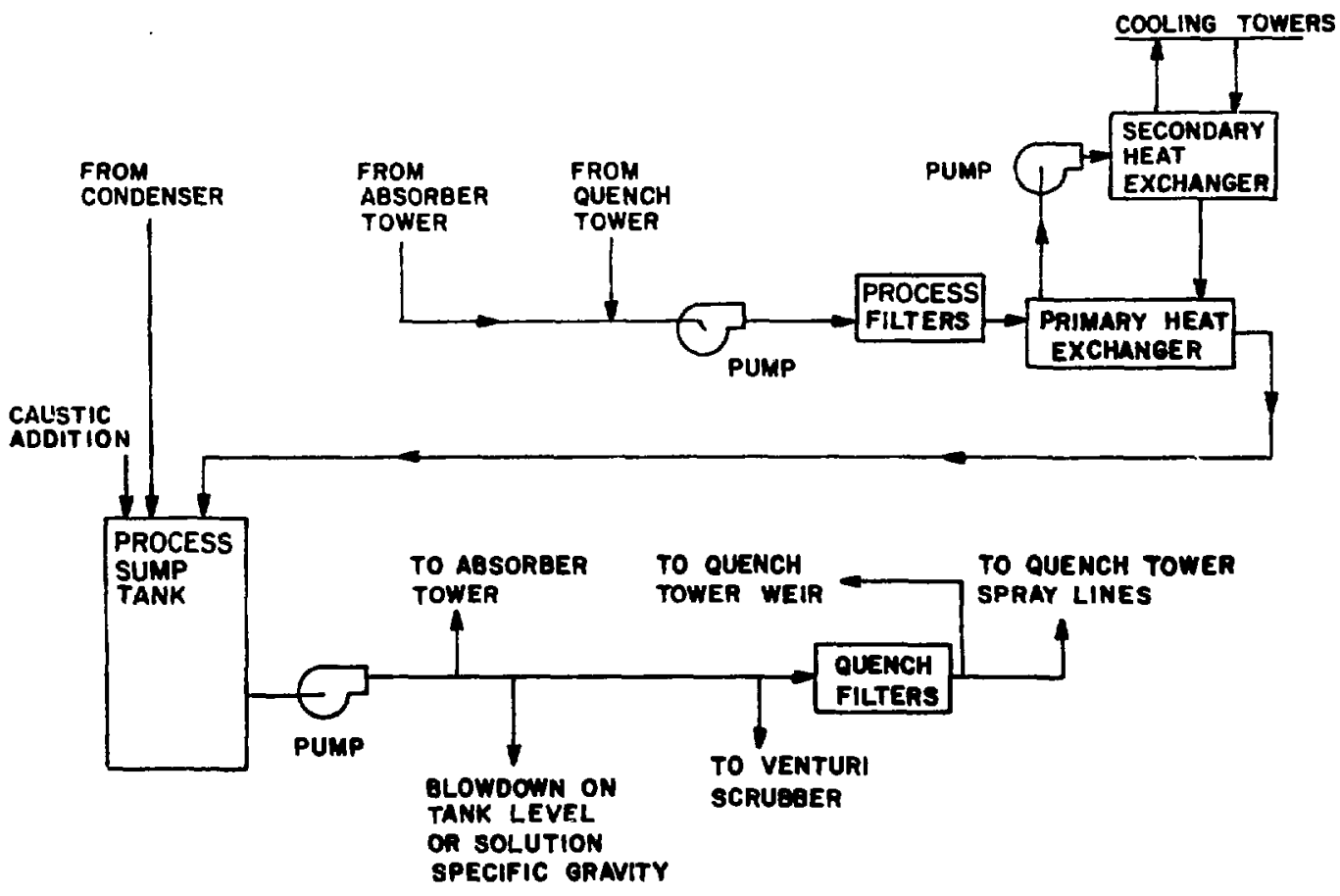

Fig. 4-8. Scrub-solution recycling syatem. 
is operated at a lower pressure than the coolant (shell) side to guarantee in-leakage in the event of tube failure. The shell-side fluid from the primary heat exchanger is cooled by the secondary heat exchange loop, previding isolation from the environment.

Cooling water is supplied to the system from either one or both forced draft, counterflow cooling towers. A secondary loop transfers heat from the primary cooling loops (primary heat exchanger and condensor) to the cooling tower. A plate-type heat exchanger serves in the secondary loop.

To control scrub-solution acidity, $20 \mathrm{wt} \%$ caustic solution is added at the process sump tank. The rate of addition is controlled by a pH sensor located on the outlet of the sump tank.

Condensate from the condensor/mist eliminator drains into a condensate receiver tank whose level is maintained by adding makeup water on demand. The solution is then pumped to the top of the packed-column absorber tower, where it is used as liquid in the absorber or routed to the process sump tank.

The blowdown rate from the process sump tank is controlled by tank level and/or specific gravity of the process liquid. If the specific gravity exceeds a specified value (currently 1.05), or if the tank level exceeds a set limit, the rate of liquid blowdown sent to the liquid waste-treatment plant increases.

\subsection{Ash Removal}

System design and component selection for the ash-removal subsystem were severely constrained by space limitations, particularly low headroom. The incinerator was installed before the start of the design process, greatly limiting workable design options. More expensive materials were used to preclude problems with corrosion, hightemperature effects, and erosion of pneumatic transport lines. Special precautions were taken to contain the ash residue within the system because the incineration process tends to concentrate the major part of the waste-feed activity in the ash.

Ash is removed through one of two paths (Fig. 4-7). A gravity ash-dropout system (GADOS) removes ash during operation and a vacuum ashremoval system thoroughly cleans out both chambers of the incinerator during shutdowns.

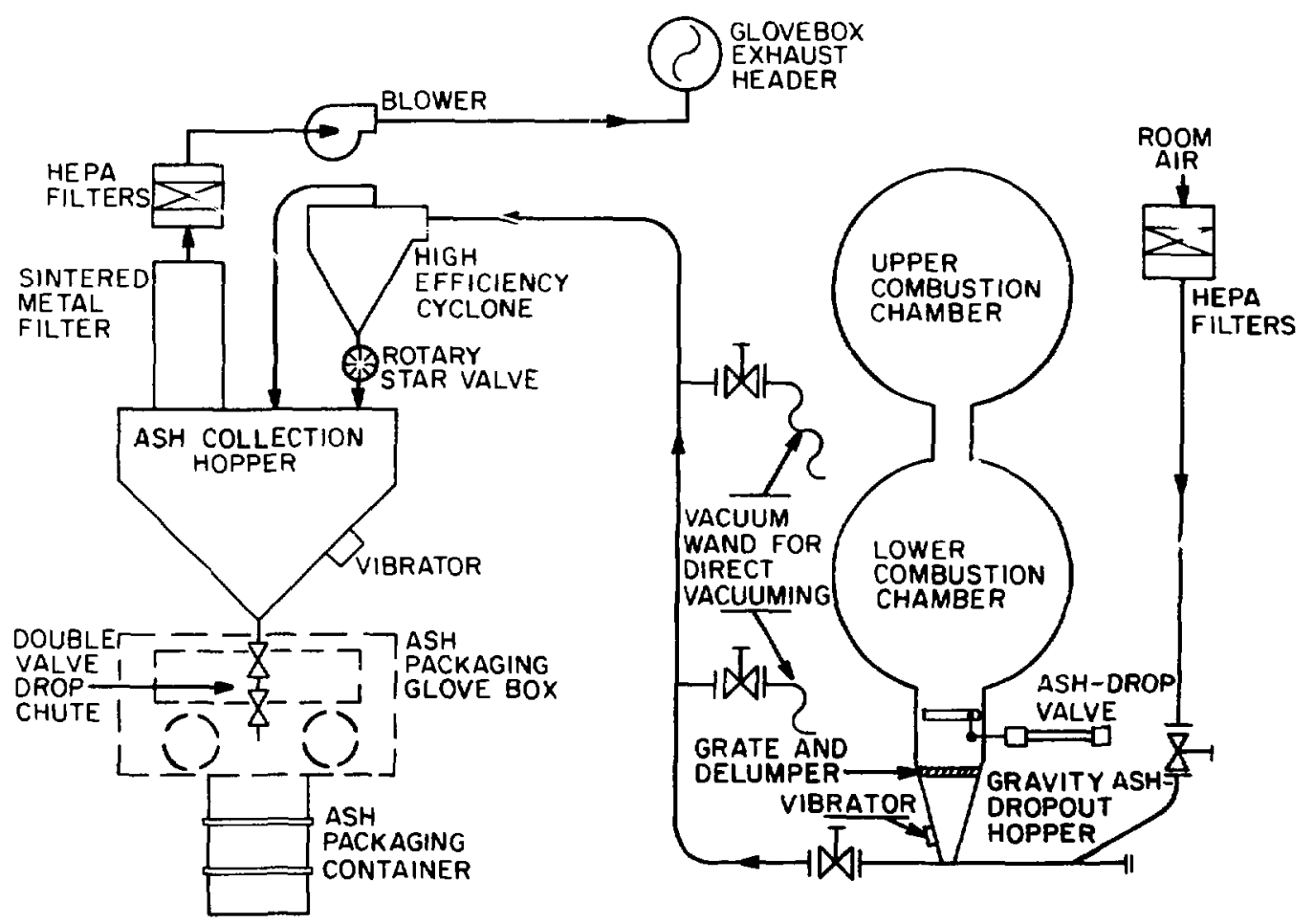

Fig. 4-7. Ash-removal subsystem. 
The GADOS consists of a refractory-lined pit and door in the floor of the primary combustion chamber of the CAl located at the end of the hearth opposite the ram feeder. As new waste is fed to the incinerator, the ash is pushed along the hearth until it drops into the ash-removal pit. The dropout door cycles on demand, allowing ash to fall through a grate and manual delumper wheel into the gravity ash-dropout hepper. The ash is then transported pneumatically from, the GADOS hopper and separated from the airsirsam by a high-energy cyclone and sintered metal filter system into the ash collection hopper where it is removed through the ashpackaging system.

The vacuum system, which can produce up to 27 kPa (1 10 in. W. G.) suction, is also used for vacuum ash cleanout during shutdown. This cleanout is achieved by manipulation of a vacuum hose in the incinerator chambers through the ash-cleanout doors and gloveboxes on the ends of the chambers.

The ash-packaging station consists of an ashpackaging bagout glovebox, where dry residue is removed from the collection hopper through a double valve drop chute. First, the upper valve is opened to allow the chamber to fill; then it is closed and the lower valve opened to drop the ash into a collection bag.

After the dry residue is packaged, it is stored for immobilization or other future studies.

\subsection{Control and Instrumentation}

Desigr, and specification of the CAl processcontrol system received priority throughout the planning and construction phase. As the nerve center for the process, the controls assure not only effective component performance but also the safety of continuing operaticss by monitoring critical variables. Control design started with incinerator operation and primary offgas components. As the design evolved, it was broadened to encompass the operation of ancillary equipment, including backup utilities.

Controls on the as-received incinerator were largely pre-set based on combustion experience for a particuiar waste composition. These sontrols were expanded to accept a vider range of feed compositions and to minimize thermal cycling in the lower chamber, where temperature is sensed to control natural gas flow to the lower burner. The flow of natural gas is measured with a hot wire, which feeds a ratio controller to meter the flow of combustion air to the lower burner. The ratio varies with desired experimental conditions. The upper burner is controlled in the same manner.

Oxygen/currbustibles sensors, positioned at the exits of the upper and lower chambers, control flows of secondary and underfire air, respectively. Steam is introduced to the lower chamber on demand during normal or shutdown conditions either by manual or automatic control. Flow measuring elements and recorders monitor air, natural gas, and steam introduction rates for energy and maiturial balances. The pressure differential between the incinerator interior and the operating area is maintained by moculating a valve immediately upstream of the induced-draft fan.

For offgas cleanup, conditioning, and filtration equipment downstream of the incinerator, the controlled variables are (1) venturi scrubber liquidfeed and pressitre drop; (2) atsorber tower liquidfeed rate; (3) condenser gas-phase temperature decrease; (4) re-heater gas-phase temperature increase; and (5) HEPA filter pressure drop. The pressure drop and nominal temperature of each component are also monitored for indications of normal or deteriorating performance.

The primary variables, and many secondary variables and parameters, are controlled and/or recorded at a central station. To aid troubleshooting, variables considered critical to process operation and safety are tied into an alarm panel which positively identifies the offrange variable and activates one of three automatic shutdown modes-controlled, fast, or emergency. Less critical alarmed variables require only operator response to correct offrange behavior.

A data acquisition system automatically records the many variable and parameter values generated during experimental CAI process runs.

\subsection{Process Utilities}

Backup utilities provide required services for an orderly process shutdown under abnormal circumstances. A diesel-powered generator is kept running during all incinerator operations, and automatic switchgear provides standby power to highconsumption equipment and vital motor driven equipment to avoid stranding components in a vulnerable operation phase. An on-line, floating battery system provides electrical power for process controls and data collection, averting potential 
momentary power interruptions, which could result in control relay dropout. A 2-h auxiliary cooling water supply is stored in a pressurized container for release to the quenching system if a recirculation pump fails. Loss of cooling water would otherwise present an immediate threat of damage to process equipment. A backup air compressor and compressed nitrogen may supplement normal instrument air supply if required. Pneumatic actuators are designed to "fail safe" on loss of air pressure. Snuffing steam is injected into the primary chamber to extinguish burning waste in the event of a fast shutdown at high temperature to prevent uncontrolled burning and iriefficient combustion, which can clog the offgas cleaning system with soot and heavy tars.

Radioisotope containment for the building is maintained by physical barriers and by ventilation in four separate zones (Fig. 4-8) The pressure of each zone is regulated so that ventilation air moves from the highest pressure zone (atmospheric) toward the lowest pressure zone (the volume internal to the process). The interface between each zone is controlled by physical enclosures.

\section{REFERENCE}

4-1. L. A. Stretz, L. C. Borduin, W. E. Draper, R. A. Koenig, and J. M. Newmyer, "Radioactive Waste Incinerator Studies at the Los Alamos Scientific Laboratory," presented at Amer. Nuc. Soc. Annual Mtg., Las Vegas, Nevada, June 9-13, 1980.

\subsection{EQUJPMENT DESCRIPTION}

The CAl process consists of six major subsystems: feed preparation, incineration, offgas

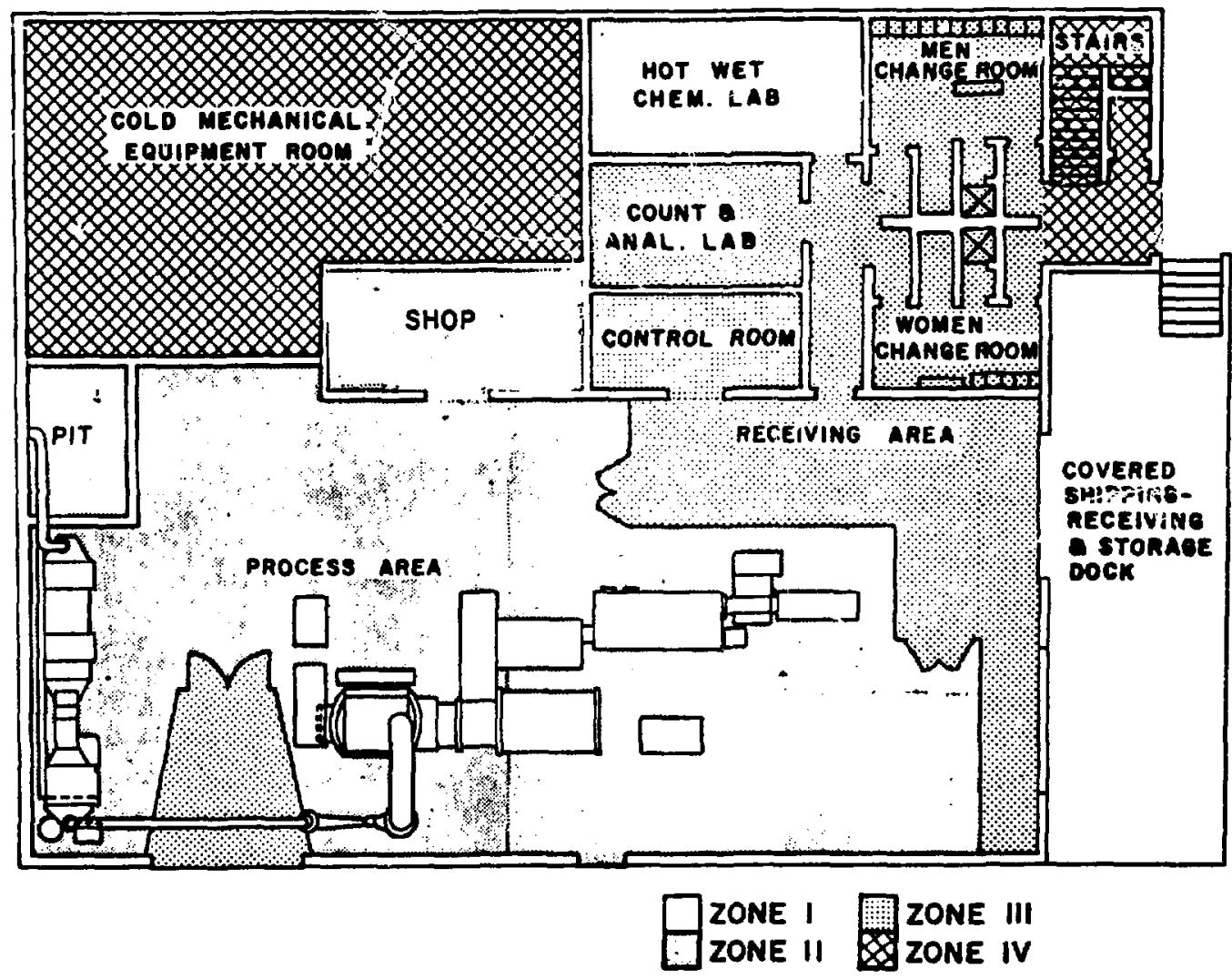

Fig. 4-8. Building ventilation for radionuclide containment. 
cleanup, scrub-solution recycle, ash removal and packaging, and process utilities. Prominent features of the design include secondary containment throughout the process to prevent alpha-contamination release, an instrumentation and control package substantially upgraded from commercial nonradioactive systems, and a high degree of purposeful redundancy among critical process components.

\subsection{Containment}

Containment provisions for all components of the CAl system received special emphasis during design. Each piece of equipment which is exposed to radionuclides was enclosed to prevent spread of contamination and to minimize the hazard to personnel during routine operation and maintenance.

5.1.1 System Gloveboxes. Each glovebox or similar enclosed wcik area has conveniently placed gloves and windows for access to normal working areas. A Los Alamos-designed gasket system precludes leaks between the windows and the box and allows easy installation and removel of the windows. The gaskets are protected from: possible heat transients by metal fireshields. All gloveboxes are provided with HEPA filtered supply and exhaust connections that draw room air into the glovebox then exhaust it to a special HEPA filtered duct. The gloveboxes are maintained at a lower pressure than working areas, so any leaks will be into the glovebox rather than into the surrounding area. Pressures are staged from the receiving slotbox to the incinerator so that air and contamination are swept into the incinerator as materials pass through the system.

Most of the gloveboxes are fabricated of no. 304 stainless steel. Others, particularly those added to the incinerator and offgas cleanup system, are fabricated of carbon steel covered with a two-coat epoxy paint system.

5.1.2. Glovebox Fire Protection. Feed preparation gloveboxes which serve as work areas for waste packages and where ignition is possible are provided with temperature-controlled spray nozzles. Limiting the water volume that can ve used in these nozzles by using an independent tank prevents spread of contamination. Gloveboxes for waste storage are fitted with heat detectors in case fire-fighting assistance is required, though at Los Alamos, the heat detectors have not been activated except for tests.

\subsection{Feed Preparation}

ine feed preparation line is dosigned to determine th a nuclide inventory of incoming TRU waste packages and to assure cumpatibility of the contents with incineration. The line consists of a receiving and storage area, package assay, microdose $x$ ray, sorting glovebox, and storage glovebox (see Fig. 4-3).

5.2.1 Receiving Slotbox. Boxed waste is introduced to the system through a receiving slotbox which also houses the MEGAS system described in Sec. 5.2.2. This slotbox is fabricated of no. 304 stainless steel and is provided with three doors for access, a bagin/bagout port for drummed boxes, tivu pneumatically operated sliding doors, a HEPA filtered exhaust and two temperature-activated wax motor sprinkler heads serviced by the limited volume water spray system.

5.2.2 Assay. Waste packages are assayed for TRU content with a MEGAS, (Fig. 5-1), developed at Los Alamos. ${ }^{s-1}$ The MEGAS provides a CAI process inventory of plutonium and americium and detects unacceptable boxes that contain fission products or gross quantities of TRU, by analyzing the electromagnetic spectrum from the 2.7-fJ (17$\mathrm{keV}) \ell \mathrm{x}$-ray region for ${ }^{239} \mathrm{Pu}$ to the 64-fJ $(400-\mathrm{keV})$ gamma region also associatsd with ${ }^{23} \mathrm{Pu}$.

The detector is a Nal (TI) crystal $127-\mathrm{mm}-(5-\mathrm{in} .-)$ diam by $50-\mathrm{mm}$ (c-in.) thick with a $0.25-\mathrm{mm}(1-i n$. beryllium window and is contained in a copperlined lead pig collinated by an iron face plate with a. $25-\mathrm{mm}(1-\mathrm{in}$.) wide by $100-\mathrm{mm}(4-\mathrm{in}$.) high viewing window. The boxes are weighed by a load cell contained in the mechanical system which raises, lowers, and rotates the package past the detector. The computerized peak-sorting analyzer combined with the automatic wojghing system eliminates the need for operator judgment. Printouts for each tox p-nvide box identlfication number, nuclide content $\therefore$ i.j type, box weight, and warnings that include high nuclide content, beta-gamma activity, and excess package weight. These data are also summed and stored in memory for later recall. 


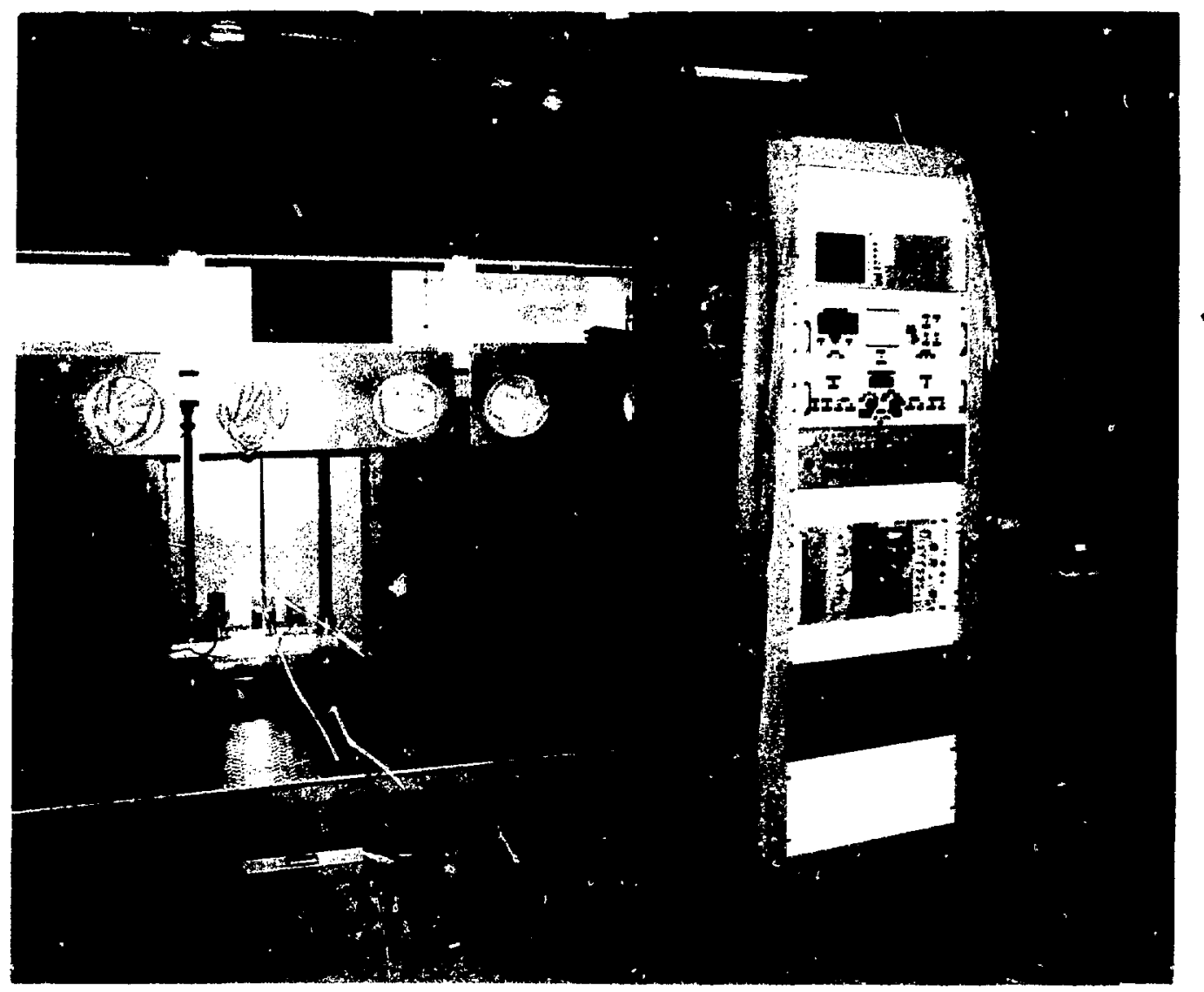

Fig. 5-1. MEGAS.

5.2.3 Microdose $x$-ray. The $x$-ray system (Fig. 5.2) used at the TDF was originally designed for airport security inspection and has been modified for scanning waste boxes. ${ }^{5.2}$ A stainless steel enclosure surrounds the conveyor belt to provide necessary airlock into the sorting glovebox.

Each waste package is $x$-rayed to detect noncombustible items (such as bottles of liquid and large metal objects). The $x$-ray system can detect wire down to $.025 \mathrm{~cm}(0.01 \mathrm{in}$.) in diameter, making objects as small as ordinary paper clips clearly discernible.

5.2.4 Sorting Glovebox. The sorting glovebox has work areas at either side and contains a sorting area, a bucket crusher, and a shredder. The hydraulically operated bucket crusher is sized to accept a 19- $(5-$ gal) bucket. It is provided with a pneumatically operated guard and is controlled from outside the glovebox. The crushing cycle is automatically controlled by a current switch to reverse the plunger. Controls prevent crusher operation without closing the guard. The low-speed shredder processes highly compacted materials with two rotating knife sets moving at slightly different speeds. It has been retrofitted with guards at its feed and exit points to prevent hazardous operation.

The sorting area is separated from tha rest of the glovebox by a weir about $10 \mathrm{~cm}$ (4 in.) high wich limits spread of waste during sorting.

Repackaging of sorted or shredded waste is facilitated by a well in the sorting glovebox floor sized to contain the standard waste package. Heat detectors and limited volume spray nozzles are provided for fire protection. 


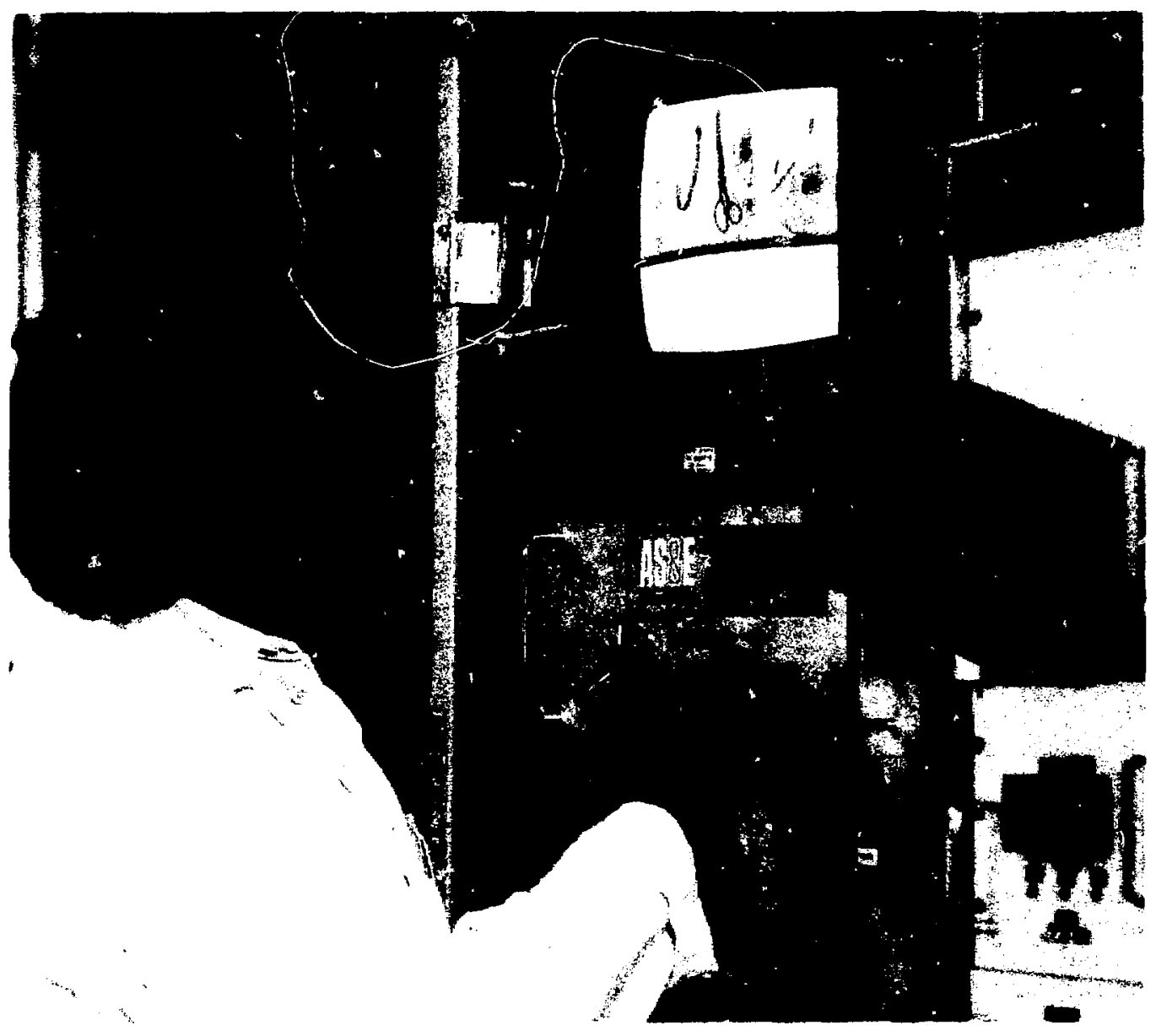

Fig, 5-2. Microdose x-ray system.

5.2.5 Storage Clovebox. The storage glovebox is fabricated of no. 304 stainless steel and fitted with pneumatically operated dors at its entrance and exit. Heat detectors are provided.

Because the incinerator demands waste feed at a predetermined constant rate, the storage glovebox provides surge capacity to couple nonconstant feed preparation rates with constant incineration demand.

\subsection{Incinerator}

The CAI is a two-stage thermal reactor that combusts solid waste feed. Its product streams are residue ash and an offgas composed of normal combustion products. The incinerator is composed of a waste package loading system, a lower combustion chamber, an upper combustion chamber, an ash-removal system, and a control system to monitor and coordinate all of these components.

\subsubsection{Waste Package Loading Syokm. Waste} packages enter the hearth of the lower combustion chamber via a main loading ram. The main ram is loaded through a separate airlock/elevator/ram system celled the side ram. A refrectory-lined guillotine door, which opens during the cherging cycle, separates the lower combustion chamber from the main ram. Operating sequences of each component are coordinated by logic circuits in the control panel to assure isolation of the incinerator from the feed preparation line. 
The main ram was supplied by the incinerator manufacturer and can charge two $.3 \mathrm{~m} \times .3 \mathrm{~m} \times .6 \mathrm{~m}$ $(1 \mathrm{ft} \times 1 \mathrm{ft} \times 2 \mathrm{ft})$ waste boxes at once. This ram is chain driven and has a 2.4-m. (8-ft) stroke. The part of the ram that extends into the lower chamber is a rectangular box with five sides covered by metal plates (the rear is not covered by a metal plate). A box rather than a plate is used to block the opening of the guillotine door to deny a direct radiation path or a ready route for combustion gases around the ram face and into the housing during loading.

Modifications to the standard main ram and guillotine door include

- Relocation of the ram chain drive under the incinerator away from the ram itself and isolation of the drive system from the ram housing by a partition. Two rods, which extend through the partition wall and are sealed by a double bellows arrangement, actuate the ram through the drive system. This modification reinoves the drive system from an area subject to contamination and thereby facilitates maintenance.

- Substitution of argon gas for the standard water spray as a fire-suppression agent. Argon eliminates cleanup problems triat follow injection of water into the housing.

- Total enclosure of the main ram and guillotine door. Enclosure materials are carbon steel with two coats of epoxy for easy decontamination.

- Elimination of the standard top-loading hatch and substitution of a side-loading door, which is a rectangular side gate designed to achieve a good pressure seal when clesed. A sideloading arrangement for the main ram was made necessary by the layout of the total CAl, in which the waste feed preparation line is at a lower elevation than the hearth of the lower combustion chamber.

- Installation of a mechanism that permits manual retraction of the main ram from ine lower combustion chamber when required. Á handoperated winch connects the rear of the main ram housing with the rear of the ram and can be operated through gioves in the rear face of the ram enclosure.

- Installation of a mechanism to lower the guillotine door manually by releasing a brake on the drive motor that elevates the door. A chain pull located at floor level releases the brake.

- Provision of a low-pressure air supply from the secondary air blower to the ram housing to offset the displaced volume created when the ram and waste feed package are moved into the lower combustion chamber. Without this provision, hot, corrosive, and potentially combustible gases would flow from the lower combustion chamber back into the ram housing each time the ram feeder cycles.

The side ram was designed at Los Alamos to move prepared waste packages from the preparation line to the main ram feeder. Each package is loaded through a rectangular slide door from the storage glovebox. Like the side-loading door for the main ram, this loading door provides a good seal when closed to allow the side ram to act as an airlock between the preparation line and the main ram feeder.

The two major components in the side-ram assembly are a pneumatically operated elevator and a chain-driven ram. The elevator raises the waste package to the elevation of the main ram feeder, and the side ram moves the waste package from the elevator through the side-ioading door of the main ram feeder and into proper position in front of the main ram. Each step in the loading sequence is triggered by the completion of the preceding step to assure safe operation.

5.3.2 Lower Combustion Chamber. The lower combustion chamber (see Sec. 4-3) is constructed to the manufacturer's standard dimensions and, for the most part, uses the manufacturer's standard construction materials. The chamber is a horizontally oriented carbon steel cylinder sealed at each end with flanged and dished heads. One head is fitted with the guillotine door assembly, the other with a large cleanout door. A full width port in the top at the end of the chamber away from the guillotine door exhausts offgases. A single burner located approximately in the middle and halfway up one side of the cylinder and oriented somewhat downward in the direction of the hearth provides auxiliary heat. The burner, a nozzle-mix type that operates on natural gas, is fitted with a sparkignited natural gas pilor. A separate blower supplies combustion air for the burner.

The chamber came with the manufacturer's standard refractory, which includes various highdensity $\mathrm{Al}_{2} \mathrm{O}_{3}+\mathrm{SiO}_{4}$ materials for hot-face service and fiber-block $\mathrm{Al}_{2} \mathrm{O}_{3}+\mathrm{SiO}_{4}$ insulating material between the high-density materials and the shell. The resulting outside shell temperature averages about $180^{\circ} \mathrm{C}\left(350^{\circ} \mathrm{F}\right)$ when the incinerator is at operating temperature.

Combustion air for the waste material enters the lower combustion chamber through underfire air 
ports and by in-leakage through the guillotine door. The average volume of air added to the lower chamber is near the stoichiometric amount required for oxidation of all combustibles. This volume typically becomes substoichiometric for a few minutes following the charge of a waste package and then becomes an excess as the slower oxidation of char begins to predominate.

5.3.3 Upper Combustion Chamber. The upper combustion chamber accepts offgases from the lower combustion chamber through a port in the bottom. The upper shamber's main function is to complete the oxidation of any combustible materials.

The construction of the upper chamber is similar to that of the lower chamber, including a large cleanout door located in one head. Exhaust from the upper chamber leaves through a port in the top at the end opposite the entrance port.

Gases that pass between the lower and upper chambers are further heated by the upper burner and are mixed with additional air (secondary air). When coupled with the residence time provided by the upper combustion chamber, this process results in conditions favorable to compiete oxidation of materials in the offgases.

5.3.4 Incinerator Modilications. Modifjcations by the incinerator manufacturer and by Los Alamos to the standard incinerator include

- Installation of a Hypalon® mastic coating between the steel shell and the Insulating fiberblock to act as a diffusion barrier to acids produced when certain compounds burn. These acid gases condense when cooled, permitting ionization and causing corrosion of the steel shell.

- Incorporation of refractory test panels in both chambers to test the resistance of selected materials to thermal shock, chemical attack, and plutonium uptake.

- Addition of a refractory-lined door in the bottom of the lower combustion chamber to reduce the ash pile during operation. This port is located at the far end of the chamber away from the guillotine door and extends the full width of the chamber interior.

- Addition of steam-injection lances in the lower chamber. Steam is used to enhance the watergas shift and steam-carbon reactions and as a snuffing medium during fast shutdowns.

- Addition of large sightports to permit better observation of the chamber interiors.
- Installation of a iarger thar standard cleanout dor" for the upper chamber.

- Replacement of the standard mechenism with a secondary air injector which uses multiple high-velocity injection ports for better mixing of the air with the offgas stream.

- Modulation of secondary air flow signalled by the upper oxygen analyzer in the control loop. Continuous offgas samplers in the exit ports from each chamber determine oxygen or combustibles present in each offgas stream.

- Substitution of nozzle-mix burners for standard excess-air auxiliary burners. Nozzle-mix burners permit containment of a large fraction of auxiliary fuel combustion in the burner block, whereas combustion of auxiliary fuel with an excess-air burner is largely outside the bleck. The tighter flame of the nozzle-mix type provides more controlled combustion when the atmosphere in the lower chamber is oxygen deficient, thus resulting in less turbulence.

- Installation of control loops to modulate the auxiliary burners in response to demands for heat rather than to operate in an ON-OFF fashion.

- Maintenance of a negative $.5 \mathrm{kPa}$ (2-in. W.G.) pressure in the incinerator through modulation of flow control valves in a pressure control loop at the inlets to the induced-draft blowers.

- Increase in the size of the combustion-air and secondary-air blowers to compensate for the effects of high-elevation operation in Los Alamos.

- Enclosing burnars, comoustion-air and secendary blowers and controls, and cleanout doors in gloveboxes for safe manipulation and maintenance of items that have a high probability of containination.

- Replacement or refurbishment of all flanged connections to make leak-tight seals.

- Upgrading the flame safeguard system to that required by industrial Risk Insurers (formerly FIA) for gas-fired systems of over 422-MJ $(400,000-B t u) / h$ heat release.

\subsection{Ofiges Cleanup}

The offoas cleanup system is a series of heat and momentum transfer, absorption, and filtration devices that reduce the concentration of chemical pollutants and potentially radioactive particles to acceptable discharge levels. The offoas train is 


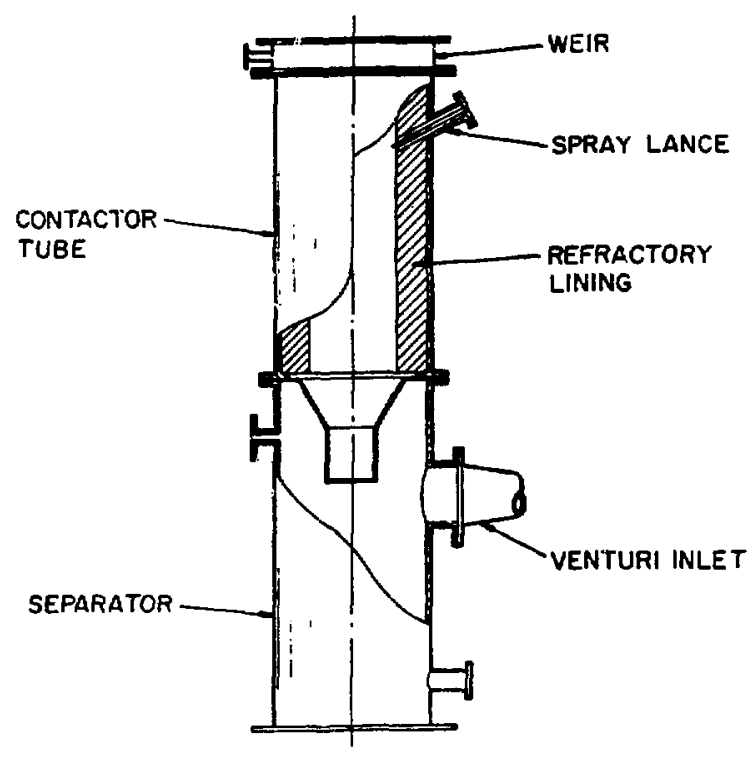

Fig. 5-3. Quench tower.

composed of a quench tower, a high-energy venturi scrubber, an absorber tower, a condenser/demister, a superheater, roughing and HEPA filters, redundant induced-draft blowers, and a control system to monitor and control each component.

5.4.1 Quench Tower. The quench tower (Fig. $5-3)$ cools incinerator exhaust from about $1100^{\circ} \mathrm{C}$ $\left(2000^{\circ} \mathrm{F}\right)$ to about $70^{\circ} \mathrm{C}\left(160^{\circ} \mathrm{F}\right)$ primarily by evaporating an injected water mist. Evaporation of the mist lowers the temperature to that of saturation. Cooling the offgas to saturation increases the efficiency of the venturi scrubber by preventing evaporation of droplets which serve as targets for intercepting entrained particles.

Hot offgas is routed from the incinerator to the top of the quench tower through a refractory-lined duct. Cooling of the offgas occurs in the top section of the quench tower, called the contactor. There, hot gases pass through a bank of water sprays that partially evaporate and cool the offgas stream by latent heat exchange. The sprays are composed of hydraulically atomized process liquid recycied from the process sump tank. Hastelloy C-276@ spray lances are oriented radially to the tower and tilt down toward the offgas flow. The volume of injected spray is three times the amount calculated to saturate the offgas stream at the highest expected offgas flow rate.
As the offgas becomes saturated, the acid constituents ionize and become corrosive. To offset the effects of these corrosives, the quench tower, venturi scrubber, and absorber tower are constructed principally of fiberglass-reinfurced plastic. To smooth the heat flux through the plastic wall of the contactor, two mechanisms are employed: a brick lining and a water film over the inner surface of the brick.

The brick for this service is standard-grade firebrick installed "loose-lay," i.e., without mortar, and cut to ac.ommodate the spray lances extending to the inner surface of the brick liring. Should the water film be absent, the brick lining will prevent hot spots on the contactor wall resulting frum the pattern coverage of the water sprays.

The water film is produced by a Hastelloy C-276@ weir encircling the top edge of the contactor section. The fluid used is recycled process liquid added in sufficient volume to maintain coverage of the interior of the contactor wall after a certain amount is evaporated by the offgas stream. This film assures that the temperature of the contactor wall does not exceed the tempe-nture of the boiling solution and does not violate the temperature tolerance of the fiberglass shell. The water film also acts as a continuous wash for compounds that condense from the offgas stream on cooling and would tend to plate out on cool surfaces.

Discharge from the contactor section is through a reduced diameter tube sized to produce enough pressure drop to entrain the remaining water film into the offgas stream. The resulting turbulence eliminates channeling of hot gases through the contactor and brings the temperature of the excess water film and spray solution into equilibrium with the temperature of the offgas after saturation, thus cooling the offgas far a her.

The lower section of the quench tower is designed as a de-entrainment device to separate excess liquid from the offgas stream by changing its direction. Excess liquid is drained from the tower for further processing before discharge or reuse, and the offgas is routed to the venturi scrubber.

5.4.2 Venturi Scrubber. The venturi scrubber reduces the level of entrained particles in the offgas stream to permit acceptable HEPA filter service life.

The three major components of the venturi are a converging section, a diverging section, and an adjustable throat in the form of a conventional clamp valve that is lined with an elastomer for corrosion resistance. Tha valve is fitted with an air 
motor that modulates valve position in response to a differential pressui 3 controller. In this way, a desired constant pressure drop across the venturi can be maintained as the flow through the venturi changes in response to waste loading anc burning cycles of the incinerator. Scrubber liquidi for the venturi is recycled process solution injected through a single nozzle in the converging duct just upstream of the throat. The spray nozzle is a wideangle hollowcone Hastelloy C-276(1) type oriented by a spray lance to aim down the centerline of the venturi toward the throat. The scrubber liquid is injected at low pressure with the nozzle serving to disperse the liquid in the offgas stream. Shearing of the liquid by the accelerating gas stream forms fine droplets suitable for scrubbing. Scrubber liquid supplied to the venturi at a constant rate does not vary with changes in the offgas flow rate.

The diverging section discharges the liquid/offgas mixture into the base of the absorber tower.

5.4.3 Absorber Tower. The absorber tower removes gaseous pollutants, principally combustiongenerated acids, from the offgas stream. The quench tower and venturi remove an appreciable amount of these pollutants by absorption and reaction with the basic recycled solution used for cooling and particle scrubbing before it enters the absorber. However, including the absorber in the treatment train assures low discharge levels of these substances and also permits the use of standard materials and devices (not constructed for corrosion resistance) downstream from the tower.

The absorber is a packed-bed tower that uses 3.75-cm (1.5-in.) Pall ring packing supported by a perforated and corrugated plate. The height of the bed is $3.3 \mathrm{~m} \mathrm{(10} \mathrm{ft),} \mathrm{and} \mathrm{it} \mathrm{uses} \mathrm{a} \mathrm{hold-down} \mathrm{plate} \mathrm{at}$ the top of the bed ? . prevent blowout of the packing during process upsets. Absorbing medium is recycied process liquid adjusted to a nominal $\mathrm{pH}$ of between 8 and 9 and distributed over the packing by a weir-trough arrangement. The base of the tower accepts gas-liquid mixture from the venturi scrubber into the space under the support tray. The deceleration and turning of the offgas stream separate the venturi liquid, which subsequently is joined with the exzess quench liquid and absorber liquid for treatment before recycling.

Discharge from the ton of the absorber tower is ducted to the c.undenszir/demister and reheater.
5.4.4 Condenser/Demister and Reheater. Offgas leaving the absorber tower is saturated with water vapor which accounts for about half the total volume of the stream. By cooling the stream, the condenser/demister reduces the water content and thereby the total volume. The nominal final water fraction is about $15 \%$. Subsequent heating of the offgas stream causes a mild superheat that dries the stream so the HEPA filters are not blinded by condensate.

The condenser is a fin-tube section with cooling water on the tube side. The tubes and fins are externally coated with a phenolic resin to protect the underlying aluminum from corrosion. The fraction of water remaining in the offgas stream leaving the condenser, and hence the system, is controlled by varying the flow rate of cooling water in response to the gas-side outlet temperature.

The demister, a chevron-type, removes entrained water droplets before they enter the reheater. Both the condenser and demister are contained in a housing that is constructed ro withstand the 27-kPa (110-in. W.G.) negative pressure capability of the induced-draft blowers. Condensate from the condenser coils and deinister passes through a drain in the bottom of the housing and is collected in a condensate sump tank. Solution : :om this tank is pumped either to the top of the absorber tower or to the process sump tank.

The reheater is an expanded section of duct containing bayonet-type electric resistance heaters. The amount of superheat induced in the offgas stream is controlled by varying the current through the heaters in response to the temperature rise across the heater section. The heater section is located between sections of curved duct just upstream and downstream of the heater which serve to block direct infrared radiation palns to the temperature sensitive demister and HEPA filter section. A high-temperature shutoff switch adjacent to the heater prevents excessive temperature rise during no-flow conditions.

5.4.5 HEPA Filters. HEPA filtration reduces the concentration of particles entrained in the offgas to a level below that required for discharge to the atmosphere. Components include a firescreen, roughing filters, HEPA filters, and a housing.

The firescreen is a perforated steel sheet installed to intercept any hoi fregments should a reheater element become dislodged and fall into the HEPA filter housing. 
A bank of roughing filters serves as a prefilter for the HEPA filters and, by removing relatively large particles, tends to extend HEPA filter life.

After the bank of roughing filters, two banks of HEPA fitters assure removal of at least $99.97 \%$ of particles $>.3 \mu \mathrm{m}\left(12 \times 10^{-5} \mathrm{in}\right.$.) from the offgas stream. These elements are surrounded by a housing that is constructed to withstand the negative pressure of the induced-drafi blowers. The housing is electrically heat traced and insulated to prevent condensation on the interior surface.

5.4.6 Induced-Draft Blowers. Motive force for the whole system is provided by one of two induced-draft blowers, each of which discharges into a vent stack.

Each blower is a multi-stage turbine type capable of boosting the offgas stream pressure 27 $\mathrm{kPa}(110$ in. W.G.). Should the blower suction pressure fall below a set value, the control system will start the standby blower and shut down the operating blower. Overheating of bearings will also cause an automatic transfer to the standby blower. Should both blowers fail during operation, the control system shuts the prucess down, and the building exhaust blower then maintains negative pressure in the process line.

The vent stack extends $4.5 \mathrm{~m}$ (15 ft) above building roof elevation. Offgas discharged from the stack is monitored for radioactivity by the Los Alamos Health Physics Group H-1.

\subsection{Scrub-Solution Recycle System}

The offgas treatment system circulates an appreciable amount of water for cooling and scrubbing, about $130 \ell$ ( $35 \mathrm{gal}) / \mathrm{min}$ in our system. To reduce blowdown of water from the process, a large fraction of this water is treated and recycled in the scrub-solution recycle system (see Sec. 4.5 and Fig. 4-6).

Components of the process liauid treatment system include process liquid filters, process liquid heat exchanger, process sump tank, quench liquid filters, pH control system, and a specific gravity control system. In addition, the base of the quench tower, absorber tower, and the condensate receiver act as sumps with level controls to provide liquid inventory and net positive suction head for transfer pumps serving each unit. Each sump has a gravity overflow loop to the process liquid sump to prevent flooding during a level controller upset.
The scrub solution is cooled by two loops. The primary coolant loop consists of a plate-type heat exchanger in common with the secondary coolant loop, the offgas condenser, a process liquid heat exchanger, and a working fluid sump tank. The primary cociant loop removes heat from the recycled scrub solution, whereas the secondary cootant loop removes heat from the primary loop and exchanges that heat with the cooling tower.

\subsection{Ash Removal and Packaging}

The ash removal and packaging subsystem consists of four major components-the GADOS, the vacuum ash-removal system, the solids separation and packaging station, and the transport air supply blower.

5.6.1 GADOS. The GADOS is attached to the bottom of the lower chamber opposite the ram feed end. The end of the hearth has been fitted with a refractory-lined pit sealed at the bottom with a refractory-lined ash door (Fig. 5-4). The door is pneumatically operated with a rotary shaft and a four-bar linkage which causes the door to invert when operated. Ash drops into the hopper through a grate and delumper assembly. The delumper guarantees that friable material is broken sufficiently for pneumatic transport. Large objects are removed from the grate through an access door and glovebox adjacent to the grate.

The stainless steel hopper normally remains at a temperature of less than $65^{\circ} \mathrm{C}\left(150^{\circ} \mathrm{F}\right)$ when ash is introduced. For maximum safety, asbestos rope gaskets seal the door to the adapter plate. Two full port ball valves isolate the hopper from the transport line. A slight negative pressure is maintained in the hopper by leakage through the door seals into the incinerator.

To remove ash from the hopper, the separator and blower are activated and the ball valves are opened. Transport air is drawn through a $.6 \mathrm{~m} \times .6$ $m(2 \mathrm{ft} \times 2 \mathrm{ft})$ HEPA filter from the room to the bottom of the hopper. A bin vibrator assists in clearing the ash from the hopper walls. After it is cleared of ash, the hopper is again isolated with the ball valves.

5.6.2 Vacuum Ash Removal. The vacuum ashremoval system is used to clean ash from either 


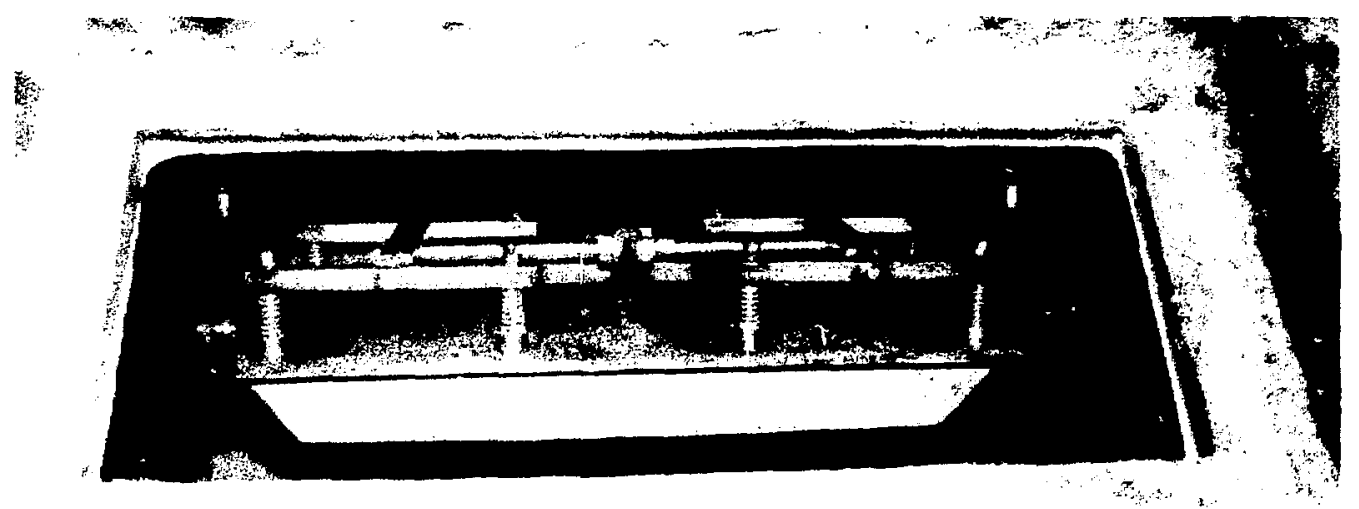

Fig. 5-4. Ash-dropout door.

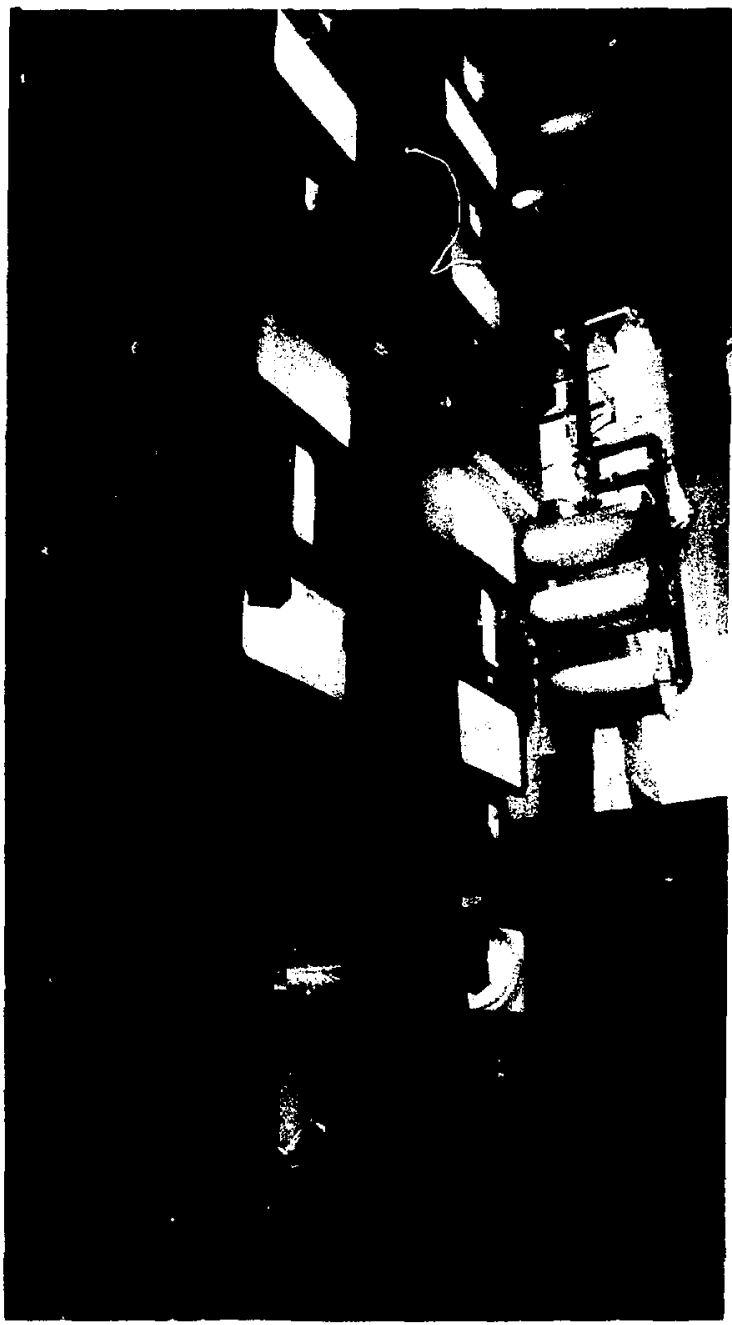

chamber following cooldown. A common pneumatic line can be valved to either the upper or lower chamber vacuum hoses. An ash-removal door, surrounded by a glovebox enclosure, is opened and the hose is extended manually into the chamber for ash pickup (Fig. 5-5). Motive force is supplied by the blower. The $8.4 \mathrm{~m}^{3}\left(300 \mathrm{ft}^{3}\right) / \mathrm{min}$ air rate at the inlet is sufficient to pick up items large enough to fit through a screen at the end of the 7.5$\mathrm{cm}-(3-i n .-)$ diam hose, which is supported and manipulated with a rod. Additional rod sections are added as needed.

5.6.3 Solid Separation and Packaging. Ash and other solids are transported pneumatically from the GADOS or one of the manual vacuum ash-removai devices to the solids separator. Transport air flows through a high-efficiency cyclone, a bank of sintered metal filters, a HEPA filter, and the blower. Solids collected in the cyclone drop through a star valve into a collection hopper. Material collected on the sintered metal filters is periodically removed by a pulse jet blowback and falls directly into the hopper.

The cyclone has a capacity of $10.6 \mathrm{~m}^{3}(375$ $\left.\mathrm{ft}^{3}\right) / \mathrm{min}$ at a $\triangle P$ of $\mathrm{C.62} \mathrm{kPa}(2.5$ in. W.G.) which results in a critical particle size (50\% efficlency) of $12.1 \mathrm{\mu m}\left(4.8 \times 10^{-6} \mathrm{in}\right.$.). The rotury star value has a capacity of $.06 \mathrm{~m}^{3}\left(2.0 \mathrm{ft}^{3}\right) / \mathrm{min}$ and serves to lsolate the cyclone from the sintered metal filter and hopper.

Fig. 5-5. Ash-removal glovebox. 
The sintered metal filter array consists of 28

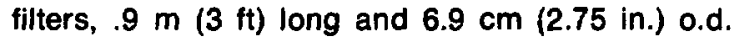
Blowbacks are placed at the outlet to each filter, and blowback pulse duration and frequency ars variable. The pulse fractures any filter cake, allowing it to fall into the hopper.

The hopper is a $.4-\mathrm{m}^{3}\left(14.8-\mathrm{ft}^{3}\right)$ inverted pyramid with a $7.5-\mathrm{cm}(3-\mathrm{in}$.$) pipe outlet into the ash-$ packaging glovebox. A vibrator on the hopper helps maintain solids flow. A high ash-level indicator is also provided in the hopper. The outlet pipe has two full-port ball valves activated sequentially to isolate the hopper and to limit the ash volume dropped at any given time into the double bagout arrangement.

5.6.4 Blower. A positive-displacement 8.4$\mathrm{m}^{3}\left(300-\mathrm{ft}^{3}\right) / \mathrm{min}$ blower capable of $27-\mathrm{kPa}(110-\mathrm{in}$. W. G.) suction at $2100-\mathrm{m}(7000-\mathrm{ft})$ elevation provides the motive force transport air and is fitted with an outlet muffler and a vibration dampening mount. A vacuum breaker on the inlet prevents blower stall should the system plug. [The blower is protected from exposure to radioactive particulates by a commerciaily available $8.4 \mathrm{~m}^{3}\left(300 \mathrm{ft}^{3}\right) / \mathrm{min}$ filter and housing.] The blower exhausts into the glovebox ventilation header to assure adequate filtration before release.

\subsection{Process Utilities}

5.7.1 Electrical Power. The TDF receives commercial power from a 13.2-kV feeder converted to 480-277 V. three phase, by a 500-kVA oil-filled pad-mounted transformer. Power is distributed to the process through a motor control center, which can also be connected to a 500-kVA diesel-powered auxiliary generator. If commercial power is interrupted, an automatic transfer switch connects the generator to the motor control center, providing power for a safe, orderly shutdown. Electrical power to the process instrumentation is supplied through a 5-kVA uninterruptible power supply (UPS) with a backup battery powered source. The UPS transfers to power from the battery pack in about $4 \mathrm{~ms}$, fast enough to prevent any perturbation in the process control or information-gathering equipment, if commercial power is lost.

5.7.2 Compressed Air Supply. The air supply at the TDF is divided into plant air supply and instru- ment air supply. The plant air system supplies the shop and certain pneumatic drives in the process area. The instrument air supply provides clean, dry air for the CAl's pneumatic controls.

5.7.2.1 Plant Alr Supply. Primary and backup air compresscrs supply air for the plant. Both compressors feed into a common $492-\ell$ (130-gal) receiver tank. Plant air supply is regulated to 690 kPa (100 psi).

5.7.2.2 Instrument Alr Supply. The instrument system was designed to be as failsafe as possible. A simultaneous failure of four compressors and a backup compressed nitrogen supply are necessary betiore total loss of motive supply to CAl process instrumentation.

Primary and backup compressors supply 410 kPa (60-psi) instrument air to the process through a regenerating desicant dryer. The plant air supply is connected to the instrument air system through a valve arrangement that allows plant air to supplement instrument air if the instrument air pressure drops beiiw a preset level. A tertiary backup is a bank of three compressed nitrogen bottles similarly manifolded and connected to the instrument air supply. With losses of both commercial power and the auxiliary generator, instrument air from the nitrogen bottles would be available for process requirements.

5.7.3 Natural Gas Supply. Natural gas is supplied to the area from a $690-\mathrm{kPa}$ (100-psi) utility main and reduced to $69 \mathrm{kPa}$ (10 psi) at the site boundary. The gas is metered before it enters the process area.

5.7.4 Plant Water Supply. Plant (nonpotable) water is supplied to the process steam generator, supply tank, process pump seals, and the caustic makeup tank. The main supply line is fitted with a backflow preventer.

\section{REFERENCES}

5-1. D. F. Jones, L. R. Cowder, and E. R. Martin, "Computerized Low-Level Waste Assay Systems Operations Manual," Los Alamos Scientific Laboratory report LA-6202-M (February 1976). 
5-2. "AS\&E Microdose X-ray Inspection System (Model 222) for Narcotics, Weapons, and Contraband Detection," American Science and Engineering Co., Inc., report ASE-3490 (April 1974).

\subsection{EQUIPMENT PERFORMANCE}

\subsection{Introduction}

The performance of the CAl as originally designed and assembled was guod. Because it is an $R$ \& D facility, the Los Alamos CAI has been changed over the years to improve its operation. The goal of Los Alamos Group H-7 is to correct process deficiencies whenever practicai as soon as they are detected.

\subsection{Feed Preparation}

Although the individual operations of the feed preparation system were for the most part simple, linking these operations increased the system's complexity to make it somewhat cumbersome and labor intensive. The experimental nature of the Los Alamos operation allows this complexity, whereas a production system would benefit from modification as discussed in Sec. 7.1 and 7.2.

6.2.1 Waste Receiving and Inspection Area. This area has served its purpose well. Handling wastes in the Laboratory stendard $.3 \mathrm{~m} \times .3 \mathrm{~m} \times$ $.6 \mathrm{~m}(1 \mathrm{ft} \times 1 \mathrm{ft} \times 2 \mathrm{ft})$ boxes with attendant markings was orderly and allowed excellent adminletrativo controls on waste generators. The sturdineas of the boxes presented little possibility of their breaking during transit and subsequent handling.

The MEGAS performed well, though high background levels resulting from its proximity to inprocess waste inventory made calibration difficult at times.

The rnicrodose $x$-ray system identlfied boxes with noncombustible materials in the waste matrix. Boxes with no large noncombustibles detected were allowed to pass to the incinerator unopened. The system's high performance was verified by the absence of large noncombustibles in the ash after each experimental run.
6.2.2 Sorting Glovebox. Manipulation of the boxes was made easier by fabricating and using special tools. The components (a bucket crusher, a waste shredder, and a repackaging well) worked very well, but the movement of materials, especially unsorted boxes, was sometimes laborious.

The waste shredder worked well when used, but operations on plant-generated waste did not require shredding. An oak $10 \mathrm{~cm} \times 10 \mathrm{~cm}$ (4 in. $\times 4$ in.) board was shredded with no difficulty during testing. Similarly, the bucket crusher was tested during cold operations, but it was used very little during operatinns on production-type waste.

The original Jesign included an ordinary kitchen trash compactor to reduce the number of waste packages processsed and the volume of waste stored in the storage glovebox. When the compactor was tested, the containment bag became hopelessly tangled in the mechanism. The dexterity required to clear the mechanism was greatly impeded by working through a glovebox. It was decided that boxing a greater volume of uncompacted waste required less effort than operating a modified compactor. In addition, it was found that the uncompacted waste burned better than compacted waste in the CAI.

6.2.3 Storage Clovebox. Minimal problems doveloped during storage glovebox operations (the storage glovebox is pictured in Fig. 6-1). Difficulties with sealing the glovebox doors were corrected by installing a roller/cam assembly to each door.

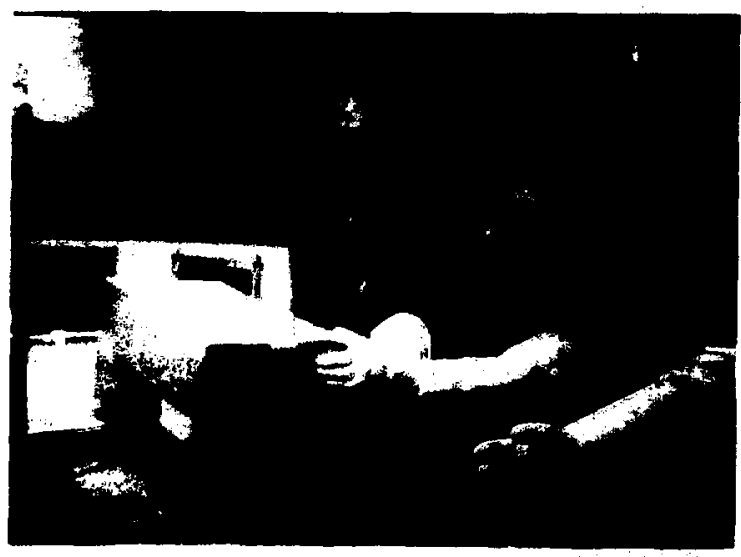

Fi. 4-1. Storage glowbox and loading dimetor. 


\subsection{Incinerator}

Overall, the incinerator has functioned safely and effectively.

6.3.1 Waste Package Loading System. The modified main ram and guillotine door have worked well with few exceptions. On two occasions, opening and closing the guillotine door snagged and tore gloves installed in the door enciosure for maintenance. In both instances, the negative pressure of the system prevented spread of contamination until the gloves were replaced.

During early operations, side feeding of the niain ram was sometimes impeded by boxes catching on the lower set of rake teeth in the main ram. Femoving these teeth solved the side loading problem but compromised the clearing action that had been provided for the advancing main ram. This modification did not present a problem with boxed waste but loose material used as feed could present a problem.

More than once, a power transient during loading dropped out certain control relays. Manual actuation of the relays was sufficient to properly sequence the main ram. Manual retraction of the main ram with ths hand-operated winch has not been required during operations to date.

The side-rar feeder has demonstrated only one problem: the tendency to chew up waste packages that are not properly loaded onto the elevator. A properly positioned package passes through the loading operation without problem, while an improperly loaded package will cause the elevator to jam while rising. Though not difficult, clearing the mechanism is bothersome and warrants a package guide on production units.

\subsubsection{Upper and Lower Combustion} Chambers. The only difficulty in operating the incinerator was the initial lack of stability of the auxiliary heat burners. Lighting and proving pilots was affected by the relatively high negative pressure in the incinerator, a problem alleviated by substitution of a different pilot/regulator combination.

Auxillary-heat burners supplied by the manufacturer were an excess-air type that produced a relatively large and diffuse flame that reached completely across the combustion chamber at high firing rates. During periods of excess combustibles in the chambers, the auxiliary fuel would compete with waste-generated combustible gases for ox- ygen introduced through the burner, resulting in a very dispersed and somewhat unstable flame. These burners were changed to a nozzle-mix type that produces a higher heat density within the burner block and results in a significantly more stable flame.

The lower combustion chamber was modified to include an ash-dropou: door in the floor of the hearth opposite the guillotine door. The mechanism for transporting the ash pile down the hearth to a position over the ash-dropout door is the feed box itself, which retains its integrity until char oxidation is nearly complete. Each charged waste package pushes the previously loaded package down the hearth until oxidation is complete, at which time the box and contents lose their original shape.

Carbon burnout in the ash has been quite good, producing a final ash with a carbon content of less than $500 \mathrm{ppm}$ during normal operations.

On several occasions, when waste containing high percentages of plastic was burned, the melted and burning plastic would tend to flow through the undertire air ports and burn in the air distribution manifolds. Though no equipment was damaged by these occurrences, they were a cause of concern because redesigning the components was a task of major magnitude. When the manufacturer's representative was informed of the problem, he said incinerators at other facilities had developed the same difficulty with burning plastic. Therefore, a product modification was made by the manufacturer and incorporated into all subsequent models.

The potentially short life of the refractory lining was a concern and is the subject of frequent questions from visitors, but the refractory has proven sound and shown very little wear. With careful selection, installation, and operation, the satisfactory performance of the refractory lining at Los Alamos can be duplicated at other facilities.

\subsection{Offoas Cleanup}

The performance of the originally designed and installed offgas cleanup system has been good, requiring no modification to achieve acceptably low discharge concentrations of pollutants. Some minor modifications have been required to increase system reliability (see Sec. 6.4.3 and 6.4.6).

6.4.1 Quench Tower. The quench tower has performed as designid with no modifications. The 
following operating parameters have proven satisfactory: $45.4 \ell(12 \mathrm{gal}) / \mathrm{min}$ weir water flow at less than $140 \mathrm{kPa}(20 \mathrm{psi})[28.3 \ell(7.5 \mathrm{gal}) / \mathrm{min}]$, spray

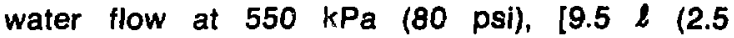
$\mathrm{gal}) / \mathrm{min} / \mathrm{nozzle}]$, sump liquid height maintained at

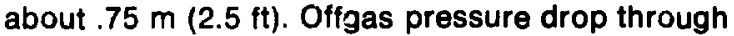
the tower has at all times been less than $0.25 \mathrm{kPa}$ (1 in. W.G.).

6.4.2 Venturi Scrubber. The venturi scrubber has been effective while it operates with a pressure drop of $12-15 \mathrm{kPa}$ (50-60 in. W.G.) and a minimum liquid-flow-to-gas-flow ratio of about $0.6 \times 10^{-3}$ $\mathrm{m}^{3} / \mathrm{m}^{3} \quad\left(\mathrm{ft}^{3} / \mathrm{ft}^{3}\right)$. Operation with higher liquid-to-gas ratio [about $0.9 \times 10^{-3} \mathrm{~m}^{3} / \mathrm{m}^{3}$ $\left.\left(f i^{3} / f^{3}\right)\right]$ is preferable but the unit is slightly underdesigned and will not pass the required offgas flowrate at the higher liquid flowrate. Nevertheless, the long operating lifetime of the downstream HEPA filters indicates that the venturi has been a very effective device for removing particles from the offgas stream.

Setup of the venturi pressure drop control loop required numerous iterations, a result of interaction with the incinerator pressure control loop. For the pressure control loop of the incinerator to be stable, the venturi control response time has to be slow relative to incinerator pressure control response time.

6.4.3. Absorber Tower. The absorber has proven effective at a liquid flux of $90 \mathrm{l} / \mathrm{min} / \mathrm{m}^{2}(2.25$ $\left.\mathrm{gal} / \mathrm{min} / \mathrm{ft}^{2}\right)$. The parking is $3.75-\mathrm{cm}(1.5-\mathrm{in}$.) polypropylene Pall rings. During one upset, the packing support plate was lifted off its support ring and subsequently, along with the packing, collapsed into the sump section of the tower. Anchoring the support plate to the ring has prevented recurrences of this problem.

Pressure drop across the tower during operations is less than $0.75 \mathrm{kPa}$ (3 in. W. G.).

6.4.4 Condenser/Demister and Reheater. During normal operation, the condenser lowers the offgas temperature by $17^{\circ} \mathrm{C}\left(30^{\circ} \mathrm{F}\right)$ and thereby removes about $5.7 \ell(1.5 \mathrm{gal}) / \mathrm{min}$ water vapor from the stream. A flow of about $265 \ell(70 \mathrm{gal}) / \mathrm{min}$ cooling water at $21^{\circ} \mathrm{C}\left(70^{\circ} \mathrm{F}\right)$ is required for the condensation.

The reheater is normally adjusted to produce about a $17^{\circ} \mathrm{C}\left(30^{\circ} \mathrm{F}\right)$ superheat.
This combination of settings has proved sufficient to pass the offgas through the HEPA filters in a dry state.

Pressure drop through the unit during operations is less than $0.25 \mathrm{kPa}$ ( 1 in. W.G.).

6.4.5 HEPA Filters. At Los Alamos, the longest HEPA filter life measured to date is $230+h$ of operation before changeout. However, that changeout was for a scheduled inspection and replacement and was not required by excessive pressure drop, so extrapolating expected HEPA filter life for normal operations from this measurement would be difficult.

Some difficulty was experienced in achieving a good seal with the "fluid seal" arrangement because after the seal was tested, the testing agency wrapped it with masking tape. When the tape was removed, part of the seal came with it, so the seei had to be carefully repacked before the filter was installed. Another problem with the fluid seals was that the knife edges were very sensitive to dirt or small movements, so they required great care in installation and maintenance.

Pressure drop across the HEPA filter module is about $0.32 \mathrm{kPa}$ (1.3 in. W.G.) during normal operations.

6.4.6 Induced-Draft Blower. The performance of the induced-draft blower system has been very good. There have bien no problems with low-flow surging or overheatad bearings. Automatic changeover from one blower to the other when required has always been smooth. The only problem areas have been low-flow switches and check valves.

Flapper, or sail-type, low-flow switches are installed at the discharge from each blower and were originally used to prove blower operation. These flow switches have never been rellable, so the blowers are now proven by a negative preasure switch in the blower inlet duct.

Low head-check valves installed at the discharge from each blower isolate one blower from the other during automatic switchover. The type thai comes with the unit is an asymmetrical flapper with an external counterbalance. These units did not prow totally reliable, particularly when both blowers are off and negative pressure for the process was being supplied by the building exhaust blowers. A spring-loaded check valve supplied by the blower manufacturer should prove more antisfactory. 


\subsection{Scrub-Solution Recycling}

The performance of the system originally designed for treating and recycling scrub solution has been good. The only major problem area was the performance of the $\mathrm{pH}$ control system (see Sec. 6.5.4). Modifications were required to increase system reliability (see Sec. 6.5.1).

6.5.1 Liquid Filters. The liquid filters are effective when assembled properly. Some problems have occurred during changeout of filter elements because restricted dexterity when working through gloves makes proper assembly difficult.

Incorrect filter assembly results in bypassing the filter. A strainer was addad downstream of the quench solution filters to provide a coarse backup should bypassing cccur. Any increase in pressure drop across the strainer is an indication of an improperly assembled filter. The filter assembly includes guides, springs, and spacers which are removed when the filters are changed. It is easy to drop these components into the bottom of the housing but hard to retrieve them.

The frequency of filter changeout depends on incinerator operations. During normal operations when underfire air is kept low and the burners are stable, ash entrainment in the offgas is low and filter life is greater than $24 \mathrm{~h}$.

6.5.2 Scrub-Solution Heat Exchanger. The scrub-solution heat exchanger performed as designed once installed. The graphite tubes al a delicate, however, and several were broken during installation of the exchanger and had to be replaced, a difficult task.

The temperature of the scrub solution is reduced about $20^{\circ} \mathrm{C}\left(35^{\circ} \mathrm{F}\right)$ in the exchanger to a temperature of about $50^{\circ} \mathrm{C}\left(120^{\circ} \mathrm{F}\right)$ during normal operations.

6.5.3 Scrub-Solution Sump Tank. The sump tank holds a constant inventory of about $2800 \ell$ (750 gal) of scrub solution. The two major problems with the tank were seals and support for an agitator.

The tank is all fiberglass construction and was fabricated with a top secured to the body with lightweight flanges. Achieving a satisfactory seal at this flanged connection is very difficult because tne flanged surfaces are irregular. The overflow loops are above the flanges so resulting leaks could have caused contamination problems. A proper seal was achieved by installing a TEFLON@ rope gasket.
The tank itself is too fragile to support and withstand vibration of a tank mixer. Therefore, the mixer had to be supported by an external steel bridge that spans the sump pit. The mixer was then sealed to the top of the tank with an expansion joint.

6.5.4 pH Control System. Combustion generated acids are neutralized by injection on demand of a $20 \%$ sodium hydroxide solution into the scrub solution. Several injection points were tried but proved unsatisfactory before the present location was chosen. Caustic is now injected at a point just upstream of where the combined blowdowin from the quench tower, venturi, and absorber tower enters the sump tank. The combined blowdown and caustic are blended in a recycle line from the discharge of the sump tank pump which re-enters the top of the tank. The tank mixer provides backmixing and the tank provides residence time necessary for smoothing. Some dead time in the control loop allows undersirable swings in the $\mathrm{pH}$.

6.5.5 Specitic Gravity Control System. We have experienced no problem with the specific gravity control system; however, blowdown from the scrub-solution sump tank caused by high specific gravity is rare. Fresh water added to the system through several pump seal water purges discharges into the scrub solution for proper disposal and tends to cause a surplus of liquid in the system.

6.5.6 Piping and Connections. Most of the liquid piping in the process is constructed of fiberglassreinforced plastic which has shown excellent corrosion resistance. However, we have found that if the procedures for fabrication and bonding are not followed exactly, leaks invariably result. Also, the pipe is fragile and is easily cracked by falling tools or other impacts. Repairing small leaks in the system is a continuing necessity.

\subsection{Ash Removal and Packaging}

As a system, the ash-removal and packaging equipment has performed extremely well. Although some components may apply to a production unit, the overall design would probably need substantial modification since the Los Alamos version was heavily constrained by space requirements and different packaging needs. 
6.6.1 GADOS. The GADOS is a unique in-house design that was severely constrained by available space. Because the hopper bottom is only a few inches above the floor, pneumatic transport to the packaging station was used. The $7.5-\mathrm{cm}-(3-\mathrm{in} .-)$ diam inlet pipe at the bottom of the hopper plugged with charred material during an early run. The large charred pieces were not typical but resulted from off-normal operating conditions (lack of underfire air). After that run, a grate and delumper were added to prevent plugging the transport lines.

Although the grate/delumper has prevented plugging during test runs, the concept could be improved for production. Access for manual operation of the delumper is inconvenient. Unsorted noncombustibles such as wire do stop the delumper and require removal. Access to the grate for removal and bagout of items is difficult. These problems could be alleviated by allowing more space under the incinerator.

The dropout door between the incinerator and GADOS hopper has operated superbly. Because the hopper is isolated from the pneumatic system during the drop cycle, ash entrainment through the lower chariber has not been observed. Further, the thermal mass of the hopper is substantially larger than the ash inventory, eliminating any temperature problem in the GADOS. The maximum hopper temperature noted has been $65^{\circ} \mathrm{C}\left(150^{\circ} \mathrm{F}\right)$ while the incinerator is operating and after door activation.

\subsubsection{Vacuum Ash Removal. The vacuum system} (Fig. 6-2) exceeded expectations in terms of solids pickup and transport capabilities. It has also been extremely effective in removing large amounts of ash from the lower chamber. High air-flow rates eliminate particulate resuspension and dusting problems during cleanout operations. Difficulties with the extension rods used to move the vacuum hose in the chambers have been experienced. Glovebox operation of the design has proven unwieldy but acceptable for testing.

The upper chamber vacuum has caused no problems but is used infrequently. Only a minor dust coating exists in the chamber, a result of high turbulence that does not allow particles to settle.

\subsubsection{Solids Separation and Packaging. The} solids separation and packaging station was designed to meet program needs rather than longterm production criteria. Ash packaging through the double bagout arrangement has proven difficult though satisfactory for handling test samples. The

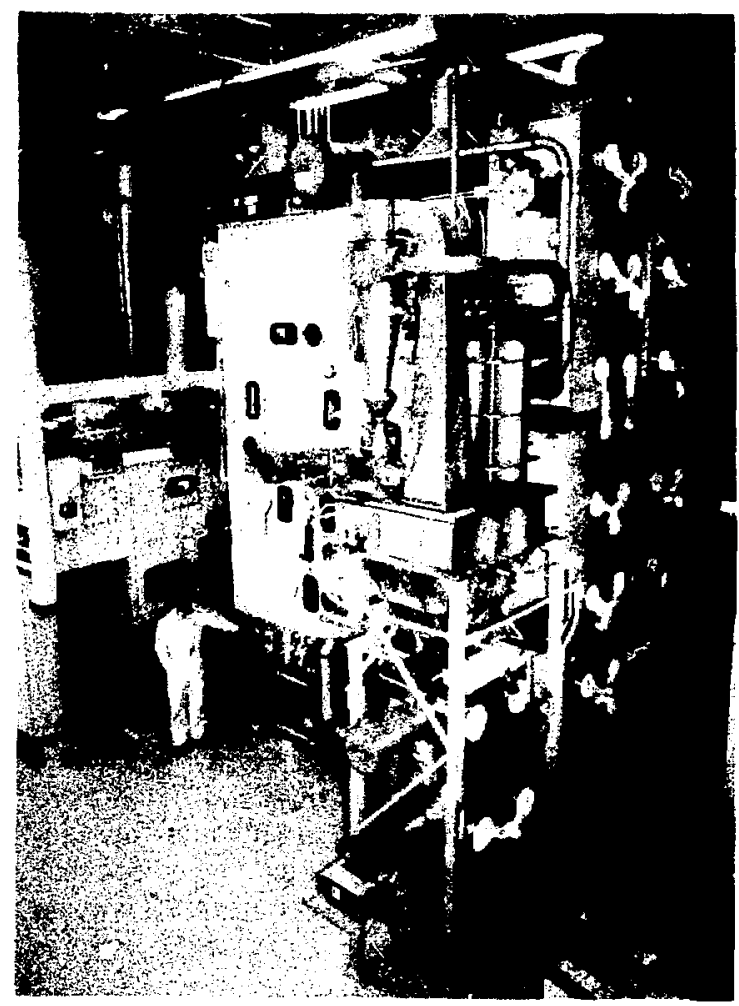

Fig. 9-2. Vacuum ash-removal syatem.

hopper, sintered metal filter components, and blowback system have proven trouble free.

During one run, the star valve under the cyclone was not started before the pneumatic transport blower was turned on. The resulting jam in the star valve required disassembly to clear but caused no interruption of the pneumatic transport. Overtiow from the cyclone was caught by the sintered metal filters. The procedural problem has been corrected by assuring that the star valve is started before the blower.

6.6.4 Filters. The HEPA filter between the sintered metal filters and the positive displacement blower required changing due to particulate loading only once during the entire testing phase.

6.6.5 Blower. The blower has been trouble tree throughout testing. The inside location of this component, is an inconvenience because of the note level in the process bay during operation of the blower. The noise is within acceptable lents because the blower is muffled and is operated inirequently. 


\subsection{Process Utilities}

Performance of the various utilities has been very good overall with the following minor exceptions.

6.7.1 Plant and Instrument Air Supplies. Carryover of oil mist and water into process components, particularly pnoumatic ones, becama a minor nuisance. Although this liquid entrainment has not caused component failure, it has led to a slower reaction time in some control loops and required cleanup of the gummed components. Installing high-capacity air dryers and larger and more numerous oil traps rellieved these problems.

6.7.2 Uninterruptible Power Supply (UPS). This system operated satisfactorily. As modifications to the process were made, additional load was placed on the UPS, which then operated near design capacity. On several occasions the system overloaded and tripped out. This overload could have been avoided by using more judicious safety factors in sizing the unit. At the beginning of process operations, however, the strain on the UPS caused by continuing modifications to the CAl process could not be predicted.

\subsection{AECOMMENDED IMPROVEMENTS}

\subsection{Introduction}

The Los Alamos CAl system was constructed to develop and demonstrate technology for reducing volume and inherent hazards in handling and storing combustible TRU waste. The building and process were designed to handle transuranics requirerl for experiments and not as an operating production facility. All subsystems were designed for easy access, simple maintenance, easy changeout, and minimum exposure of personnel to contamination.

The experimental nature of the system led to some compromises that would not be acceptable in a production facility. Other design features permit data acquisition and/or process control beyond the needs of a production facility. The test program has shown where modifications or additions are required to facilitate production waste processing. This section describes features in the Los Alamos CAl system that differ from those recommended for a full-scale production facility incinerating large quantities of TRU waste.

\subsection{Feed F reparation}

Recommendations for the waste receiving and preparation subsystem are directed primarily to upgrading materiais-handling techniques for production.

7.2.1 Waste Receiving and Inspection Area. A MEGAS is recommended for waste package assay. The CAI MEGAS was state-of-the-art at the time of installation, but subsequent improvements (MEGAS II) ${ }^{7 \cdot 1}$ have upgraded assay capabilities. Future installations should consider systems available at selection time. The assay equipment should be hard-wired to the uninterruptable power supply to prevent loss of software from power failure.

Packages should be inspected with microoose $x$ ray systems on an open conveyor so they may be directed either to a sorting line or directly to a storage line. Because the CAl microdose $x$-ray is a dated design, advances such as real-time inspection, automatic sorting, and multiple-beam systems should be considered in any now installation.

7.2.2 Waste Introduction. The present receiving glovebox for introducing packaged waste into the feed preparation system can be eiiminated if a separate assay and $x$-ray inspection area is provided. Problems in keeping the conveyor belt centered have developed, but these, too, would be eliminated by a separate assay and $x$-ray area. Airlocks should be provided on both the sorting and storage gloveboxes to allow direct entry of packaged waste to either box after initial assay and $x$-ray inspection. Independent exhaust ventilation connections for these airlocks would provide more positive contamination control.

7.2.3 Sorting Giovebox. An area isolated from the sorting operation should be provided for the waste shredder, bucket crusher, and glass crusher. Alsc, improved access for operation and maintenance should be provided. An efficient discharge and collection system is required for the glass crusher. The waste compactor has been removed from the present system because it was found to be unnecessary. In fact, compacted wastes have reduced burning efficiency in the incinerator (see Sec. 6.2.2).

Including metal detectors for inspecting repackaged waste should be considered. The sorting glovebox layout should allow a straight flow 0 . materials through the box with process operation 
stations along this pathway. Some staff prefer including a center conveyor with work stations on both sides. The box should be flat bottomed and smooth throughout to facilitate materials and equipment movement. Currently, the sorting glovebox has two repackaging wells: the first, which housed the waste compactor, is no longer needed; the second, designed to aid in repackaging hand-sorted waste, is still desirable. An interior vacuum cleaner should be provided to assist in cleanup of fine materials.

Conveyor equipment is needed to move equipment within the box. The conveyor should be able to transfer equipment to a large bagout port provided with an external cover to protect the bags and an internal cover to hold the bag in place. This bagout system could be similar to the bagout arrangement of the process HEPA filters.

7.2.4 Storage Glovebox. A larger storage capacity for prepared feed is needed. Though the present box accommodates 4 to $6 \mathrm{~h}$ of feed, a minimum of $8-h$ feed storage is recommended. The box should have gloveports along each side, and a conveyor system should be considered.

7.2.5 Incinerator Feed. The side-ram feeder and feed elevator subsystem vere required for the CAI because of the single-floor design of the building. Consideration should be given : $\mathrm{g}$ gravity feed to the main ram and to an airlock to isolate the feed preparation line from the incinerater feed system.

At present, ash is transported down the incinerator hearth by displacement each time a fresh package is charged. The success of this transport method may require the box to be aligned with the long axis of the box pointing downhearth. Therefore, any alternate feed design should make the box come to rest in the main-ram feed with the long axis of the box parallel to the centerline of the lower chamber.

A hydraulically driven ram with manually operated override for retraction is recommended in place of the present chain-drive system. The ram face should be constructed of no. 310 stainless steel with refractory facing. The ram assembly should be lighter and sized to feed a waste package with a minimum-dimension side facing the incinerator. If a hydraulically operated gulllotine door sized to the waste package dimensions replaced the present electric motor drive, reliability would be increased, and shroud size would be reduced. The ram does not need rake teeth if the waste is contained in packages sturdy enough to maintain their integrity through the loading cycle.

Cleanout can be expedited by ready access to the ram housing, which should be fabricated of stainless steel with smooth surfaces and rounded corners to facilitate cleaning. Design should consider location and spacing of gloves and mecilanisms to minimize the possibility of moving parts tearing a glove.

7.2.6 Miscellaneous. Running all glovebox services and utilities in overhead ducts and trays would provide accessibility and serviceability. Efficient seals, stainless steel glovebox doors, hydraulic door actuators, and easy maintenance should be considered. Glovebox line layouts and convenient access are recommended for efficient materials throughput.

\subsection{Incinerator}

Incinerator design should address increased efficiency and control and enhanced interfacing with containment components.

7.3.1 Materials Residence Time. The CAl is designed to burn $45 \mathrm{~kg}(100 \mathrm{lb}) / \mathrm{h}$ of TRU waste material consisting of approximately one-third paper and rags, one-third plastics, and one-third rubber. The unit has been operated at rates up to $45 \mathrm{~kg}(100 \mathrm{lb}) / \mathrm{h}$ with a variety of simulated and actual TRU waste, including waste matrices of up to $50 \%$ piastics. During challenge campaigns at $45 \mathrm{~kg}$ $(100 \mathrm{lb}) / \mathrm{h}$ with frequent ash removal through the gravity ash-removal door, carbon content in the ash increased to 1-2 wt\%, apparently because of the effect of shortening the hearth, and thus residence time, by an ash dropout door. Also, particle burnout in the secondary chamber was reduced. $A$ longer hearth is recommended to increase solids.. retention time in the lower chamber. Increasing the size of the upper chamber is recommended to provide a retention time of $2.0 \mathrm{~s}$ at design feed rate rather than the present $1.25 \mathrm{~s}$.

7.3.2 Burner Modifications. Some problems in controlling temperatures in the primary chamber at $45 \mathrm{~kg}(100 \mathrm{lb}) / \mathrm{h}$ throughput of high-caloric-comient waste materials indicate a need for higher bumer turn-down ratio and capability to operats the 
burner in a pilot-only mode. If the recommendation for a longer primary-chamber hearth is followed, two burners would provide a faster and more uniform unit heatup. A burner to handle liquids and/or slurries should be considered for facilities that might be required to incinerate these materials.

7.3.3 Underfire Air. With present orientation, the horizontal underfire air-injection ports could possibly become plugged if plastic materials were to melt and flow into the ports. A new configuration with downward angled ports would alleviate this problem while maintaining proper air-ash contact.

7.3.4 CAl Component Orientation. Design of a production CAl system should give very careful attention to component location. Orientation should facilitate access, ease of operation, and maintenance while minimizing personnel exposure. Suggested specific improvements to the existing process are as follows.

7.3.4.1 Chamber Orlentation. Offset the upper chamber to the side to improve access to the lower chamber and permit possible removal and replacement without disturbing the upper chamber. The upper chamber should be offset away from the feed and ash-handling systems to provide access.

7.3.4.2 Controls Layout. CAl controls and services should be located away from the incinerator. Separate housing of blowers, instruments, etc., to faciitate maintenance and maintain cleanliness is highly desirable.

7.3.5 Incinerator Fabrication. A radioactive waste incinerator should be constructed with tighter dimensional and fabrication tolerances than used for normal industrial units. The existing unit's somewhat loose tolerances have presented problems. Spare connections should be included in the design to facilitate future additions or modifications. Flanged connections should be used so that welding directly onto the unit will not be required because welding after installation of the refractory eventually will cause failure of the mastic liner that protects the steel shell from corrosion.

Close attention should be given to design, materials selection, and craftsmanship. The refractory design should provide for expansion cracks rather than allowing random refractory temperature-stress cracking. Refractory should be installed in the field, if possible, after the unit is installed and all systems are conriected. A refractory study currently underway in the Los Alamos CAl may provide additional insight into materials selection.

More viewing ports would allow closer observation of burner flame characteristics and combustion efficiency inside the incinerator. These ports should have improved air purges to keep the lenses clear and should have accesses to permit periodic cleaning.

The present incinerator ash-removal doors are difficult to operate from a glovebox. An improved system, possibly a vertically operating door with cam locks, is recommended.

Thermal shields should be installed to limit heat transfer to operating areas and could also preheat combustion air effectively.

7.3.6 Combusion Air Glovebox. All incinerator controls and combustion air blowers should be housed in a glovebox separated from the incinerator, and/or more adequately shielded from the incinerator shell heat. An airlock entry and removal port are needed to facilitate maintenance.

\subsection{Ofigas Cleanup}

Fiberglass piping, the use of which was imposed by budget constraints, has been leak-prone, and fiberglass vessels lack structural strength to support heavy objects. Process components should be constructed of lined steel for improved safety and reliability. The design fiowrate of the scrub system should increase by approximately $10 \%$ to accommodate flow transients observed while incinerating high plastic-content waste at the design feed rate.

7.4.1 Quench Tower. The quench tower (see Fig. 7-1) should ho fabricated of steel with an internal protective lining for structural strength and corrosion resistance. This vessel supports heavy piping and would be subjected to high temperatures in the event of a loss of coolant flow. A higher flow, lower liquid pressure quench might be considered, although there has been no problem with the present design. A low-pressure design would increase the height of the column and reduce scrub-solution filtration requirements. Minor plugging in the quench-solution-supply strainer 


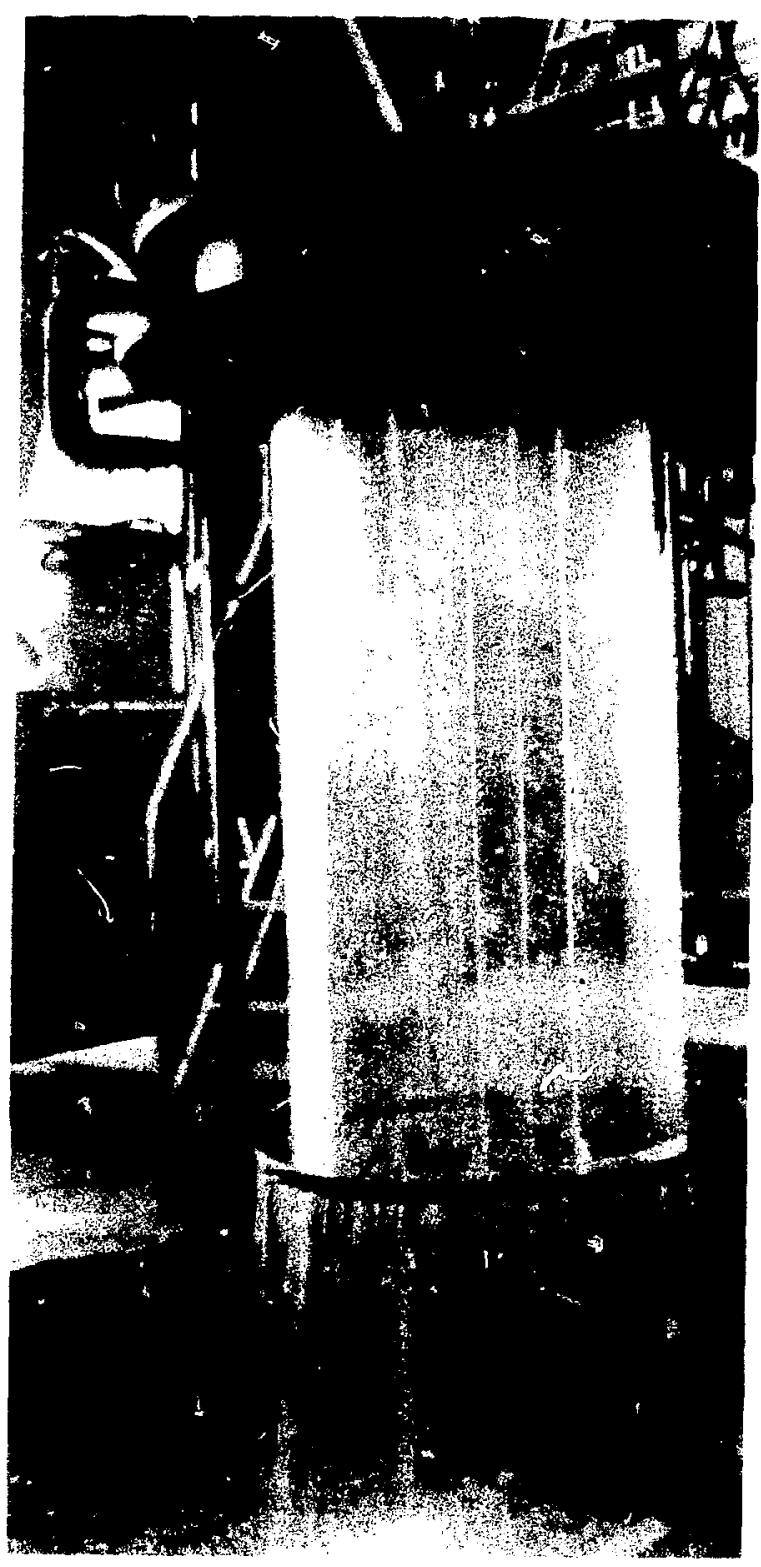

Fig. 7-1. Quench weir during pre-installation testing.

indicates a need for redundant full-cupacity paraliel strainers. A conical or dished bottom (instead of a flat bottom) and large Inspection ports are recommended in the quench tower to facilitate solids removal.

7.4.2 Absorber Tower. Tower vessels should be fabricated of steel with a corrosion-resistant lining and should be provided with conical bottoms to facilitate drainage and with larger access and inspection ports above and be!ow the packing. Packing materials should also be selected to withstand high temperatures in the event of loss of quenchsolution flow. Bottom support plates should be anchored and a top hold-down plate provided to secure the packing and liquid distributor.

7.4.3 Piping. All piping should be flanged steel construction with corrosion-resistant lining. The present fiberglass system with glued fittings frequently develops leaks at joints and is subject to mechanical damage. Therefore, careful attention silould be given to layout to assure that lines are properly sized and drain freely with drain connections provided at low points.

7.4.4 Offgas Condenser. Because chloride levels have been very low at this point in the system (10 ppm normally and up :200 ppm when the absorber tower is inoperativ $\because$ ), a standard off-theshelf stainless steel exchanger can be considered for this service.

7.4.5 Process HEPA Filters. Because an upflow filter system performs wel! for potentially saturated gas streams, it should be considered. Filter life has been good $(200+h)$ in the existing system, but filter changeout has been troublesome. A push/pull changeout system with single filters installed in multiple parallel housing would facilitate changing while on-line.

\subsection{Scrub-Solution Recycle System}

Operational problems in the scrub-solution recycle system have occurred mostly in the liquid filter glovebox (Fig. 7-2). Since access to the present filters for changeout is difficult, redesigning this system is needed to improve positioning and handling. Lighter lids and hinged covers would help, and increased ventilation would prevent window fogging in the glovebox when hot filters are exposed.

7.5.1 Primary Heat Exchanger. The present graphite tube exchanger is fragile. Although no breakages have occurred in service, some have occurred during shipping and installation. A more rugged unit is desirable, though probably more expensive. The closed seconidary coolant loop is 


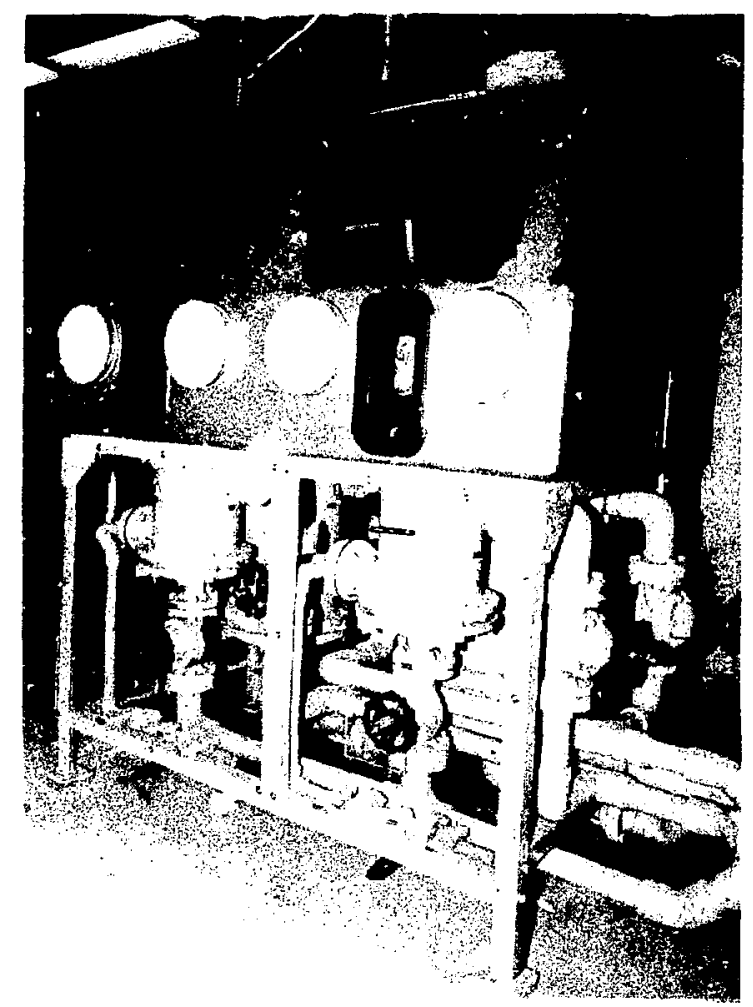

Fig. 7-2. Liquid filter glovebox.

required to provide an additional containment barrier for TRU isotopes captured in the scrub solution.

7.5.2 Pumps. Sealess pumps should be provided. Scrub-solution blowdown is currently forced by seal waier makeup rather than specific gravity ruildup.

7.5.3 Process Sump Tanks. These sump tanks should be steel, lined with a suitable polymer, and provided with a bottom drain to facilitate solids removal. Two parallel, sealess pumps located external to the sump tanks and connected to the bottom drain are preferable to the present top entry, flange-mounted sump pump.

\subsection{Ash Removal and Packaging}

Problems in the ash-handling system have resulted from nonstandard materiais in the incinerator feed and from nonstandard operating procedures. Itims such as wire, pieces of metal, etc., occasionally get through the feed inspection and sorting process to cause problems in the ash system. Improper use of bin vibrators has caused ash compaction and bridging. Ash-system design depends on the type of material handled and the method finally chosen for ash processing and disposal. Therefore, the design of the ash-handling system must be tailored to fit specific requirements of the process application.

7.6.1 Ash-Dropout Door. Because this system has been so effective and trouble free, no changes are warranted.

7.6.2 Ash Grate and Delumper. If a gravity ashtransfer system is used, the ash grate and delumper might not be required, although some methods of ash assay may require density and particle uniformity. These pieces of equipment were installed specifically to alleviate problems with the vacuum ash-transport system caused by tramp metal, wire, etc. At present, an improved means for retrieving these materials from the delumper is needed, although a part of the problem is imposed by space and access constraints. The delumper manual operation should be replaced with a motor drive unit with clutch and overload shutdown to protect the motor in the event of stalling.

Some ash presently ends up between the delumper and side walls of the ash chute because the delumper does not extend across the full width of the chute, again, because of space constraints. Full-width chute coverage and steep sidewalls are needed for optimum performance.

7.6.3 Bin Vibrators. Bin vibrators on the ashdropout and ash-packaging hoppers should interlock with dropout valves or the vacuum transfer system to assure that they can operate only when valves are open or the transfer system is operating. Otherwise, the vibrator tends to cause compaction and bridging.

All ash-transfer lines should have full-port valves. Careful attention must be given to line sizing, transport velocities, ash character, and system hydraulics. Ash-transport lines should have a minimum number of bends, and where bends are needed, long-radius ells should be used. Air-blast systems should be provided at the bottom of all sloping bins to alleviate bridging. 
7.6.4 Vacuum Ash-Transport System. The entire vacuum ash-transport system has worked very effectively, but operating experience so far is insufficient to evaluate erosion problems. No thermal problems have developed from the large thermal mass of the transfer system relative to the ash. However, high-temwerature gasket materials should minimize the possibility of thermal degradation throughout the system. Where temperatures permit, O-ring seals are recommended.

The vacuum wand for combustion chamber cleanout is difficult to handle through gloveports. Its length and weight and the necessity to add tube segments to reach the back of the chamber decrease operability. Thus, an improved system is needed.

7.6.5 Ash Packaging. The ash-loadout system design depends on and must be integratod with ash processing and disposal system requirements. The present system could be improved by adding a pressure-equalizing enclosure around the ashpackaging area. However, an ash-transport assay system and glovebox are currently in design to replace the present bagout system.

\subsection{Process Control}

The Los Alamos CAl system, which was designed for experimental purposes, is heavily instrumented to aid data accumulation and to control a wide variety of process variables. A production system requires less instrumentation for process monitoring. However, controls required for operation and safety should have as great a degree of automation as do those of the Los Alamos system.

7.7.1 Fed Charging. The feed charging system is automated to permit incinerator feeding on a timed cycle. Manual override to stop, retrieve, or reinitiate feed is needed. If the ram could be retracted any time during the charge cycle, the system would be even safer.

7.7.2 Inert Gas System. Argon, which is difficult to obtain and relatively expensive, is now used as a quench gas at the incinerator charging door, but a more readily obtained and cheaper quench medium is recommended.
7.7.3 General. A minicomputer is resommended for monitoring operations, data accumulation, and control logic. The present system, of proven reliability at the time of installation, has many electro-mechanical relays that make reprogramming more difficult. Alarm setpoints. logic, etc., could be changed more easily with a minicom. puter than with the present system, which requires wiring changes. The computer control system would also iniprove records management and permit trend analysis of input data, a desirable feature for troubleshooting and preventive maintenance.

7.7.4 Gas Analysis. Monitoring oxygen levels at the primary and secondary combustion chamber exits is recommended for diagnosis. Levels of $\mathrm{O}_{2}$ vary too rapidly and too widely to be useful in controlling air flow to incinerator chambers. Carbon dioxide and/or carbon monoxide monitoring are/is not required if $\mathrm{O}_{2}$ levels are accurately monitored.

7.7.5 Burner flame Monitoring. Some problems caused by high temperatures at the instrument location developed in the ultra-violet (UV) detection instrument that monitors the burner flame. These problems were resolyed by heat shielding. State-of-the-art fiber-optic systems with UV transmission capability should be evaluated as a means of providing a more remote instrument location for flame monitoring.

7.7.6 Incinerator Gas Supply. The present system for controlling air and fuel gas flows to the 7 \& $D$ incinerator is too complex for production application. A constant fuel-to-air ratio should be adequate. The hot-wire anemometers presently used for metering gas flows are too delicate for a production unit.

7.7.7 Offgas Systems. Instruments and controls in the offgas train have performed well. Because the present system has more instrumentation than a production facility needs, some thermal sensors and safety interlocks could be eliminated if offgassystem components were of lined steel rather than of FRP.

7.7.8 Liquid-Level Systems. Because the present sonic-type liquid-level switches have been troublesome, they have been replaced by 
hermetically sealed float switches. State-of-the-art sensing and control systems should be investigated for any new facility.

\subsection{Building}

Process equipment should be installed in an area or building spacious enough for operation, maintenance, and component changeout. The process layout shou!d be inicorporated into the building design to assure optimum use of space.

7.8.1 Compartmentalization. Subsystems should be compartmentalized to assist containment, contamination control, and heat removal. Ventilation systems should co ifine and limit the spread of TRU contamination. Substantial ventilation is required in the process area because the incinerator and other equipment create high heat loadings.

A separate area for receiving, monitoring, and storing packaged waste materials is needed to eliminate potential cross contamination of receiving and processing areas, to mitigate the consequences of a storage area fire, and to provide more storage. The package assay area should be separated from the storage area to reduce background radiation.

7.8.2 Service Equipment. Overhead cranes or other conveyance systems with capacity to handle large gloveboxes and incinerator combustion chambers should be provided since the life of the facility will exceed that of many components.

\subsection{Utilities}

System utilities and support systems design depends on existing services and design philosophy at an individual plant site. The comments made below should be generally applicable; however, because of site-specific characteristics and local codes, appropriate judgment should be exercised in adopting these features.

\subsubsection{Uninterruptible Power Supply} (UPS). Separate dedicated UPS systems should be provided for both the central TRU-waste incinerator deta acquisition and control system and the "GGAS to prevent software loss (Sec. 7.2.1). These modifications are recommended even though the existing UPS system for process instrumentation and control has performed very well.

7.9.2 Auxiliary Power Supply (APS). The APS system (diesel generator) is operated during test runs to assure that auxiliary power is available at all times. A reliable, quick starting APS system should be considered to eliminate the need for continuous idle of the generator during normal operations. Replacement in the offgas system of FRP equipment wih lined steel equipment could eliminate the need for auxiliary power idling. Auxiliary power requirements should be carefully studied as a part of any future project.

7.9.3 Fuel Gas Supply. The gas supply line should be doubly contained with the outer line vented outside the building to assure safety. Automatic gas-supply shutoff upon activation of the fire alarm system is also recommended.

7.9.4 Plant Water. A plant water supply pressure in excess of $690 \mathrm{kPa}$ (100 psi) gauge is desirable so this system can back up the auxiliary water system. Makeup water must be screened and filtered to keep particulate matter out of the process.

7.9.5 Auxiliary Water Supply. Auxiliary water is a critical safety system because it supplies backup quench water to the offgas system when primary flow is lost. Indeed, it has been called into service on several occasions. To assure reliability, a system such as this must be carefully engineered with no manual block valves between the tank and quench spray lances. The system is bled down automatically on process shutdown, and any required maintenance can be scheduled for nonoperating periods.

7.9.6 Process-Protection System. The limited water-volume process-protection system should be replaced with a system using HALOND or another agent. The ultrasonic level indicator in the water supply tank is not reliable in this service.

7.9.7 Steam Supply. A plant steam system, if available, would be preferable to the present electric boiler. 
7.9.8 Air Supply. Lines of stainless steel tubing are recommended for both plant and instrument air systems to eliminate scale. Drains and traps should be provided at low spots.

7.9.9 Caustic Feed and pH Control. To achieve a more constant $\mathrm{pH}$ value by caustic neutralization of the process liquid, the caustic should be introduced into the supply line before it enters the sump tank. The volume of caustic injected should be in response to a signal from a pH transmitter in the tank outlet line.

\section{REFERENCE}

7-1. D. A. Close, C. J. Umbarger, L. West, W. J Smith, M. R. Cates, B. W. Noel, F. J. Honey, et. al., "Transuranic Waste Assay Instrumentation: New Developments and Directions at the Los Alamos Scientific Laboratory," Journal of the INMM 1, 503 (1978).

\section{ACKNOWLEDGMENTS}

We acknowledge the direction of T. K. Keenan and $L$. C. Borduin and the efforts of the following in developing the CAl process: L. E. Esquibel, C. L. Gilley, H. Gomez, R. Kuoppla, D. Melton, D. C. Nelson, C. Peterson, R. Ridlon, J. Rutten, L. A. Stretz, T. K. Thompson, and S. K. Yeamans.

We thank P. Baldwin, M. L. Vigil, and J. C. Whorton for their work on the document. 


\title{
Edited by Jill Warren
}

Photocomposition by Barbara J. Velarde

\author{
Assisted by E. Katherine Valdez
}

\section{DISCLAMMER}

This report was prepared as an account of work sponsored by an apency of the United States Gownment. Neither the United States Government nor any agency thereol, nor any of their employen, anken any warrenty, express or implied, or asumes any lopl linbiltty or responeibility for the accuracy, comeletemen,

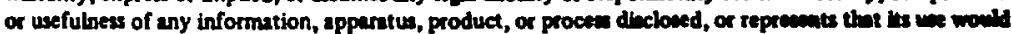
not infringe privately owned rights. References herein to any spectife commercial product, proces, or

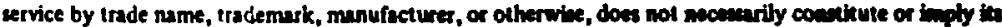
endorsement, recommendation, or favoring by the United States Comernment of any apacy therwof. In. views and opinions of authors expresued herein do not mecessarily state or reflect those of the Uniled States Government or any agency thereof. 